\title{
Firm geographic location and voluntary disclosure
}

\author{
Imen Derouiche \\ Unité de recherche CREA, University of Luxembourg \\ Kaouther Jaafar \\ Ahmed Zemzem* \\ University of Sousse, Tunisia
}

\begin{abstract}
This study aims to shed light on the effect of a firm's geographic location on its voluntary disclosure policy. It hypothesizes that a firm's geographic distance from metropolitan areas increases the cost of oversight of managerial actions, which creates incentives for remotely located firms to make more voluntary disclosures in their annual reports that improve information available to investors and hence mitigate agency conflicts. Based on a sample of 260 French listed firms spanning the period 2007 to 2010, we find support for our hypothesis that as a firm's distance from the Paris region increases, its level of voluntary disclosure in annual reports increases as well. This is consistent with the notion that remote firms are likely to pre-commit to higher voluntary disclosure so as to reduce oversight costs arising from geographic remoteness and mitigate agency conflicts. Our results are robust to alternative measures of voluntary disclosure, to several geographic location proxies, and to alternative estimation techniques. Collectively, they confirm the positive effect of distance on the extent of voluntary disclosure.
\end{abstract}

Keywords: Geography; Firm location; Agency costs; Voluntary disclosure JEL Classification : G30; R39; D21; D22

\section{Introduction}

Despite technological advances, firm geographic location still plays a major role in determining investment decisions. Firm proximity to core investors such as mutual funds,

* Corresponding author: High Institute of Business Studies, University of Sousse, Sahloul III, PO Box 40, 4054, Sousse, Tunisia; Email: ahz963@yahoo.fr; Phone: +216 27499159.

We would like to thank the referee for his helpful comments and suggestions. All errors are our own responsibility. 
hedge funds, investment banks, and financial analysts increases firm visibility and makes the task of monitoring by external shareholders less costly. Therefore, proximate investors, both individuals and institutions, exhibit a higher propensity to invest in geographically proximate firms. Anecdotal evidence shows that many venture capitalists prefer to fund start-up companies that are located within a 20-minute drive from their offices. For instance, the social networking website Facebook moved its base of operations to Silicon Valley in 2004 to benefit from easier access to venture capital; one year later it received its first round of financing from Accel Partners, located just four blocks away from (Tian, 2011).

The literature on the relevance of geography in finance has grown since the findings of Coval and Moskowitz (1999, 2001) that investors prefer stocks of local companies. It is argued that geographic proximity provides investors with better access to firm local information, and hence is associated with better investor return (Ivković and Weisbenner, 2005), more accurate analyst forecasts (Malloy, 2005), and better price formation in securities markets (Pirinsky and Wang, 2006). More recently, several studies show that a firm's geographic location plays a critical role in shaping corporate behavior, such as firm financing, investment, and payout decisions (Loughran, 2008; John et al., 2011; El ghoul et al., 2012, among others).

The present paper sheds additional light on the agency motives for voluntary disclosure and examines the impact that firm geographic location has on voluntary disclosure policy. We argue that firm geographic location affects the ability of outside investors to monitor and oversee firm management and, as a consequence, its voluntary disclosure policy. We posit that decreased observability of managerial decisions in remotely located firms leads to high oversight costs by outside investors, and we hypothesize that remote firms are more likely to make more voluntary disclosure to mitigate these costs. Our conjecture is consistent with agency theory, suggesting that less monitoring by outside shareholders may encourage self-interested managers to engage in corporate misbehavior, such as empire building and consuming perks, which in turn reduces firm profitability and destroys its value. To reduce potentially high oversight costs incurred by outside shareholders, firms pre-commit to greater voluntary disclosure (Jensen and Meckling, 1976). In this perspective, Healy and Palepu (2001) discuss how disclosure can reduce agency costs by providing outside investors with a tool for monitoring, which improves their ability to relate managerial decisions to firm 
performance. Considering this line of reasoning, geographic location is likely to matter in explaining firm voluntary disclosure choices in the presence of agency costs.

Our key conjecture is that distance to metropolitan areas is associated with increased monitoring costs by outside shareholders. Indeed, geographic distance decreases the ability of outside shareholders to oversee and monitor managerial actions, thereby increasing oversight costs that shareholders face. Unlike local investors, distant investors are less likely to inspect remotely located firms and to acquire knowledge about the management and internal operations. Gaspar and Massa (2007) argue that shareholders located away from company headquarters are less prone to undertake valuable monitoring activities, due to the higher costs of understanding the technical aspects of a firm's internal operations and obtaining information about the management culture.

The objective of this research is therefore to generate empirical evidence on the relation between a firm's geographic location and the extent of its voluntary disclosure in annual reports, within the agency theory framework. We specifically focus on the decision made by insiders to voluntarily disclose additional information in annual reports in a setting characterized by greater agency problems. We argue that geographic distance reduces the effectiveness of external monitoring by limiting the observability of managerial actions, and hence encourages remotely located firms to adopt voluntary disclosure practices in a way that improves information available to investors. Our analysis is conducted on French firms, which are characterized by a high level of concentrated ownership, and where the controlling shareholder is often at the helm of the firm (Faccio and Lang, 2002). In such an environment, the main agency problem arises between dominant shareholders and minority investors, rather than between managers and shareholders. Using geographic remoteness as a proxy for monitoring costs, we investigate the impact of firm geographic location on its voluntary disclosure policy in a setting characterized by greater agency problems between controlling and minority shareholders.

We use the distance between corporate headquarters and the Paris region to proxy for monitoring costs. We suggest that firms headquartered inside the Paris region have many potential investors nearby, while remotely located firms have fewer investors in their vicinity. Therefore, firms headquartered in and around the Paris region are expected to have lower 
monitoring costs, whereas firms headquartered far away from the Paris region are expected to have higher monitoring costs.

The present study is conducted in the French context, which presents an interesting, if not unique, setting for addressing the effect of distance on voluntary disclosure. First, ongoing corporate transparency challenges have urged French authorities to draw up several guidelines to encourage listed firms to increase their voluntary disclosure, such as Bouton report and Afep-Medef codes on corporate governance. French firms are, however, typically controlled by dominant shareholders who are more willing to take advantage of firm opacity to obtain private benefits of control. These opposite forces at work on corporate transparency make it interesting to address the issue of voluntary disclosure in France. Second, except for the study of Boubaker et al. (2015) examining the effect of geography on corporate cash holdings, there is no research linking geography and corporate practices in the French context. Different from the U.S. featuring metropolitan decentralization, the Paris region is considered as the unique influential metropolitan area in France (Guillain and Le Gallo, 2010). All these factors make of France a suitable laboratory for examining how remoteness from metropolitan areas can affect the extent of voluntary disclosure.

To test the impact of firm location on the extent of voluntary disclosure in annual reports, we use a sample of 1,040 firm-year observations for 260 French listed firms spanning the period 2007 to 2010. We hand-collect data on voluntary disclosure from firms' annual reports. We analyze the content of the annual reports of sampled firms to determine the level of voluntary disclosure of each company based on a self-constructed index following prior voluntary disclosure studies. We find that as firms' distance from the Paris region increases, the extent of voluntary disclosure in their annual reports increases. This result supports our hypothesis that greater distances from metropolitan areas increase information distortions in remotely located firms, which reduces the observability of managerial actions to shareholders. Thus, remote firms have greater incentive to voluntarily disclose more information in their annual reports to improve information available to investors and increase firm value. Moreover, our results are robust to alternative variable definitions and to alternative estimation techniques.

This research contributes to the literature on the effect of geographic proximity on corporate finance decisions. It empirically tests the impact that a firm's location has on its 
voluntary disclosure policy. There are a handful of papers in the corporate finance literature that examine the relevance of geography on corporate policies. For instance, Loughran (2008) highlights that rural firms are less likely to conduct seasoned equity offerings compared to urban firms, since geographic remoteness inhibits outside investors, who are at a significant information disadvantage regarding remotely located firms, from buying rural stocks in the event of an offering. At the same time, Kedia et al. (2008) report that acquirers earn significantly higher returns in geographically proximate transactions. Landier et al. (2009) highlight the importance of a firm's geographic dispersion on its labor and divestiture policies. Almazan et al. (2010) examine the impact of firm location on its acquisition and financing choices. These authors report that firms located in industry clusters tend to have more investment opportunities, and require increased cash to undertake more acquisitions.

Second, our research contributes to the voluntary disclosure literature by generating evidence on the impact of firm geographic location on voluntary disclosure practices. Voluntary disclosure is deemed to improve information available to investors, which allows them to better monitor managers (Jensen and Meckling, 1976). Information problems are likely to be greater in remotely located firms, due to the increased monitoring costs in remote locations. Our results show that distant firms are more likely to disclose additional information in annual reports to increase information flow in the market and, hence, mitigate monitoring costs by outside investors. To the best of our knowledge, the current study is the first to examine the impact of firm location on voluntary disclosure policies in an agency theory framework.

The remainder of this paper is organized as follows. Section 2 reviews the literature and develops research hypothesis. Section 3 describes data and variables' construction. Section 4 presents methodology, results of multivariate analysis, and robustness checks. Section 5 concludes.

\section{Literature review and hypothesis development}

This study is motivated by a growing literature on the economic importance of geographic proximity. Coval and Moskowitz (1999, 2001) analyze the effect of distance on investment performance and find that U.S. mutual fund managers are better at picking stocks of firms located in their vicinity than stocks of firms located farther away. Hau (2001) note 
that German traders located in proximity to corporate headquarters outperform other traders, since they have better access to first-hand and low-cost information about corporate policies. In the same vein, Ivković and Weisbenner (2005) report that individual investors exhibit a strong preference for local stocks than mutual fund managers. In the area of equity analysis, Malloy (2005) highlights the role of geographic proximity in improving the performance of financial analysts. The author finds that geographically proximate analysts produce more accurate earnings forecasts, update their forecasts more frequently, and have a greater impact on stock prices than distant analysts. O'Brien and Tan (2015) indicate that remotely located firms that go public are more inclined to use local analyst coverage in a way to increase visibility with other analysts and institutional investors. Li and Zhao (2016) find evidence that stock returns have stronger comovement with the returns of nearby firms than with those of distant firms. Focusing on bank sector, Hollander and Verriest (2016) document that increased distance constraints faced by lenders in acquiring borrower information lead to more restrictive bank loan contracts.

Unlike the above-mentioned studies, our research analyzes the effect of a firm's geographic location on the extent of voluntary disclosure in its annual reports. In particular, it focuses on how geographic remoteness from metropolitan areas can be conducive to poor information environment, hence encouraging corporate insiders to voluntarily disclose additional information as a way that mitigates this adverse location effect.

Consistent with the agency theory, voluntary disclosure plays an important role in mitigating the conflict of interest between insiders and outsiders. Comprehensive empirical studies support the theoretical prediction on the effectiveness of voluntary disclosure in reducing agency costs. Healy and Palepu (2001) review the disclosure literature and report that voluntary disclosure provides outside investors with a useful monitoring tool that helps to mitigate agency problems and effectively monitor managerial decisions. Ali et al. (2007) analyze disclosure practices of U.S. firms and show evidence that family firms facing severe agency problems between controlling and minority shareholders carry out better financial disclosure compared to non-family firms. Boubaker et al. (2014) find that, consistent with the alignment hypothesis, insiders of French firms have less incentives to withdraw firm-specific information or to hoard bad news. Boubaker et al. (2015) show that controlling shareholders accumulate more cash into private benefits when their firms are headquartered outside the Paris region, suggesting that geographic remoteness can be conducive to severe agency 
problems. Abdulkadir and Schwienbacher (2016) stress that voluntary disclosure on investments in innovative startups is strategically used by large firms to signal the market.

There is empirical evidence in support of the view that geographic distance from a firm's headquarters impacts monitoring and oversight costs of the management team. A potential explanation of this view is that, as firm distance from metropolitan areas increases, the observability of managerial investment decisions decreases, hence making monitoring costly for outside investors. Petersen and Rajan (2002) study the concept of physical distance in the context of commercial banks' lending to small companies and find evidence that banks are more reluctant to provide credit to more distant firms, since lower visibility and difficulty in maintaining close formal and informal relationships with borrowers are more likely at greater distances. Mian (2006) highlights that foreign banks shy away from lending to domestic banks that require relational contracting and explains that this reluctance is related to additional agency costs that arise from cultural differences and geographic remoteness. Chen et al. (2010) document that venture capital firms are likely to locate in metropolitan areas with the highest concentration of profitable investments, so that they can benefit from decreased costs of oversight and can easily monitor managerial actions of their portfolios companies. John et al. (2011) report that geographic distance from U.S. metropolitan areas increases the cost of shareholder oversight of managerial actions, hence incentivizing remote firms facing free cash flow problems to increase their dividend payouts as a way to mitigate such costs. Ayers et al. (2011) show that managers are more likely to use opportunistic reporting discretion when the monitoring institutions are located at a greater distance from the firm's headquarters. In a similar vein, Chhaochharia et al. (2012) contend that local institutional investors are effective monitors of corporate behavior, since geographic proximity to firms' headquarters provides investors with better ability to assess managerial actions and inspect firm operations. Boubakri et al. (2016) find that decreased remoteness from financial centers of metropolitan areas is associated with increased foreign investors' ownership, suggesting that increased monitoring of management mitigates the adverse effect of geographic remoteness.

Based on these arguments, we claim that geographic distance increases information distortions and, hence, decreases the observability of managerial actions to outside investors. Voluntary disclosure improves information available to investors, hence serving as an effective tool for reducing costs of monitoring management. Agency theory posits that 
insiders have incentives to incur bonding costs and provide valuable firm-level information to outside investors, since they can produce information about their activities at lower cost. Accordingly, remotely located firms' awareness of the difficulty of monitoring by outside shareholders strengthens their incentives to undertake higher firm-level voluntary disclosure. Hence, we expect that as firm distance from the Paris region increases, the extent of voluntary disclosure in annual reports increases as well, ceteris paribus. Therefore, we expect that the extent of voluntary disclosure increases with distance from the Paris region.

\section{Data and variables construction}

This section describes the sample selection procedure, lists our data sources, and discusses construction of the voluntary disclosure index and control variables, as well as the results of the univariate analysis.

\subsection{Data sources and sample selection procedure}

Our initial sample encompasses all French listed firms appearing in the Worldscope database in the period 2007-2010. Firm annual reports are downloaded from the website of the French market authorities (www.amf-france.org) as well as from firms' websites. Data on latitudes and longitudes of the location of the firms' headquarters are collected from Maps of World (www.mapsofworld.com). Data on alternative measures of distance are obtained from the www.viamichelin.com website. Data on analyst following are obtained from the Historical Institutional Broker Estimation System (IBES) International database. All other financial data are obtained from the Worldscope database.

The final sample of our study is constructed as follows. First, as in previous studies, we exclude regulated utilities (SIC codes between 4900 and 4999) and financial firms (SIC codes between 6000 and 6999), because such firms operate in an environment with specific legal and regulatory requirements. Second, we rule out firms that are headquartered in the French Overseas Departments and Territories, because the considerable distances between these regions and the Paris region may distort the location analysis. Finally, we discard delisted firms and those with missing financial data. The final sample consists of 260 firms with 1,040 firm-year observations covering the period 2007 to 2010 with complete data for analysis. 


\subsubsection{Measurement of the voluntary disclosure index}

To measure the level of voluntary disclosure in annual reports of French listed firms, we use a self-constructed index based on prior voluntary disclosure literature (e.g., Meek, Roberts and Gray, 1995; Botosan, 1997; Eng and Mak, 2003). Previous studies on voluntary disclosure use different proxies for the overall level of disclosure, such as earnings forecasts (Karamanou and Vafeas, 2005; Chen et al., 2008), analyst disclosure ratings (Lang and Lundholm, 1993, 1996; Healy et al., 1999), and annual report disclosures (Botosan, 1997; Cheng and Courtenay, 2006). In the current research, we focus on the latter proxy, consistent with the findings of Lang and Lundholm (1993) that annual report disclosure levels are positively correlated with the amount of disclosure provided via other avenues, such as investor relations and other publications.

The voluntary disclosure index contains 95 discretionary items and is reported in Appendix 1. Index items fall into two categories: governance information and financial information. Governance information includes matters that cover boards of directors, compensation committees, and audit committees. Financial information includes matters such as stock price information, projected information, and other financial data. As in Cooke (1992), content analysis was conducted to identify the presence of any information in annual reports. A dichotomous procedure was applied in which an item scores 1 if it is disclosed, zero if it is not disclosed, and N/A if it is not applicable. The voluntary disclosure index was compiled using the relative approach; DSCORE is the sum of scores awarded for each item in the index divided by the maximum possible score. The latter was calculated after excluding non-applicable items. Thus, companies are not penalized if a disclosure item is not relevant to it (e.g., some firms have no compensation committee or audit committee). The disclosure index is derived from the following formula:

$\operatorname{DSCORE} E_{j}=\sum_{i=1}^{95} \frac{S \operatorname{SCR} E_{j}}{\max \left(S C O R E_{j}\right)}$

where $S C O R E_{j}$ is the total number of points awarded to firm j, and max $\left(S C O R E_{j}\right)$ is the maximum score awarded to firm $\mathrm{j}$ after excluding all irrelevant items for that firm. Hence, $D S C O R E_{j}$ is our measure of the extent of voluntary disclosure in annual reports of French firms, calculated as the total number of items awarded to each firm in our sample divided by 
the maximum possible score for each firm. Similarly, we construct the governance information score, GSCORE, and the financial information score, FSCORE.

Consistent with prior research on voluntary disclosure, the use of self-constructed indices has some limitations. Botosan (1997) documents that a self-constructed index is a useful research method that gives strong and corroborative results. However, this methodology requires subjective assessment by data collectors, which constitutes its main limitation. Consequently, it is important to assess the validity of our self-constructed index. First, we follow a number of researchers (Botosan, 1997; Gul and Leung, 2004) and use Cronbach's coefficient alpha (Cronbach, 1951) to measure the internal consistency of our proxy of voluntary disclosure. This tool is used to assess the degree to which correlation among the categories is attenuated due to random error. Generally, an alpha of 0.8 is a good indicator that correlation is attenuated very little by random measurement error. In our case, we find that Cronbach's alpha for the two categories of the disclosure index is 0.56, suggesting that random measurement error can reduce the power of the empirical tests in our study. Following Botosan (1997), we may accept a relatively low Cronbach's coefficient alpha. ${ }^{1}$

Second, we examine the correlation of our proxy of voluntary disclosure DSCORE and various firm characteristics, consistent with prior research. We find that DSCORE is positively and significantly associated with firm size, leverage, profitability, audit firm size, analyst following, market-to-book ratio, cross-listing, and security issuance. This finding is consistent with prior research on voluntary disclosure that examines the association between disclosure level in annual reports and various firm characteristics, as analyzed in Ahmed and Courtis (1999). Overall, the validity of DSCORE is supported by its correlation with various firm characteristics documented in prior research and by Cronbach’s coefficient alpha.

\subsubsection{Measurement of a firm's geographic location}

Consistent with prior research, we use a firm's headquarters as a proxy for its location (Coval and Moskowitz, 1999, 2001; Ivković and Weisbenner, 2005; Kang and Kim, 2008). Davis and Henderson (2008) show that corporate headquarters are considered the center of information exchange between the firm and its investors. We gauge the distance from a

\footnotetext{
${ }^{1}$ Botosan (1997) finds a relatively low alpha of 0.64, but this author considers the disclosure measure valid.
} 
firm's headquarters to the Paris region as a metric of its location. The Paris region is the wealthiest and most populous region in France. It is home to large French corporations and a large number of financial operators, such as financial analysts, investment banks, mutual funds, pension funds, and brokerage houses (Guillain and Le Gallo, 2010). According to a recent survey conducted by Ernst \& Young, the Paris region hosts the headquarters of 67 of French firms on the Forbes 2000 list. $^{2}$ Further, this region contains the major business and financial districts in France, with approximately 45 million square meters of office space (Halbert, 2004). The Paris metropolitan area is composed of eight departments centered on its innermost department and capital, Paris. The inner ring consists of three departments namely Haut-de-Seine, Seine-Saint-Denis, and Val-de-Marne, and the outer ring consists of four departments namely Seine-et-Marne, Yvelines, Essonne, and Val-de-Oise. Overall, according to the economic importance of the Paris region in France, we consider it a reference point to measure our three proxies of geographic location used in the empirical analysis.

To determine the firm's geographic location, we first obtain the location of the headquarters of each firm in our sample using the four-digit postal code of the county in which the firm is headquartered. Then, we construct our three proxies of geographic location. First, we measure the variable DISTANCE, defined as the natural logarithm of one plus the distance in kilometers between the firm's headquarters and the Paris region. Following Coval and Moskowitz (1999), we use the following formula to measure the distance between two points, a and b:

$$
\begin{aligned}
& \text { Distance }_{a b}=\arccos \left[\cos \left(\text { lat }_{a}\right) * \cos \left(\text { long }_{a}\right) * \cos \left(\text { lat }_{b}\right) * \cos \left(\text { long }_{b}\right)+\cos \left(\text { lat }_{a}\right) *\right. \\
& \left.\sin \left(\text { long }_{a}\right) * \cos \left(\text { lat }_{b}\right) * \sin \left(\text { long }_{b}\right)+\sin \left(\text { lat }_{a}\right) * \sin \left(\text { lat }_{b}\right)\right] * 2 \text { Л r/360 }
\end{aligned}
$$

where (lat) and (long) are latitudes and longitudes (measured in degrees) of the Paris region and firm headquarters locations, and $r$ is the radius of the earth $(6378 \mathrm{~km})$.

Second, we compute the variable ROAD DISTANCE as the natural logarithm of one plus road distance in kilometers to the Paris region. Our choice of road distance is motivated by the recent study of Mento (2009), who finds that the automobile is still a primary mode of

\footnotetext{
${ }^{2}$ Ernst \& Young “European Headquarters: Location decisions” survey, 2009.
} 
transportation, suggesting the importance of highways in facilitating accessibility to a given city.

Third, we code a dummy variable, which we label OUTSIDE_PARIS, to take the value 1 if the firm is headquartered outside the Paris region, and zero otherwise. As mentioned above, the Paris metropolitan area is composed of eight departments; we consider them our reference point to gauge this variable. Firms are considered to be located in the Paris region if they are located in one of the eight departments of Paris (75), Haut-de-Seine (92), Seine-Saint-Denis (93), Val-de-Marne (94), Seine-et-Marne (77), Yvelines (78), Essonne (78), and Val-de-Oise (95).

\subsubsection{Control variables}

\subsubsection{Firm size}

Prior studies document a positive association between firm size and the extent of disclosure in annual reports (Lang and Lundholm, 1993; Raffournier, 1995). From the agency theory standpoint, large firms have higher agency costs. Thus, they are more likely to disclose more information to reduce these costs. In addition, the political cost theory suggests that large firms are generally exposed to political attacks and pressures from government and regulatory bodies (Watts and Zimmerman, 1986). Therefore, large firms may reduce these actions through voluntary disclosure. Finally, the benefit cost theory argues that large firms incur lower disclosure costs because they already produce information for internal purposes, explaining their incentives to disclose more information than small firms, which are generally more reluctant to disclose additional information for fear of competitors (Singhvi and Desai, 1971). Overall, these arguments suggest a positive relation between firm size and voluntary disclosure. We measure firm size (SIZE) as the natural logarithm of total assets.

\subsubsection{Leverage}

Firms with more debt in their capital structure need higher disclosure levels to reduce agency costs of debt. According to the free cash flow hypothesis, managers may use firm free cash flow to overinvest in inefficient projects (Jensen, 1986). Consequently, shareholders can monitor self-interested managers and reduce free cash flow at their disposal through issuing debt. Jensen and Meckling (1976) argue that as debt increases, agency costs between shareholders and bondholders increase, such as costs associated with asset substitution and 
underinvestment problems. Bondholders will then demand greater disclosure. This may lead to a positive association between leverage and voluntary disclosure, consistent with the findings of Ahmed and Courtis (1999) that 29 studies on voluntary disclosure confirm a positive relation between disclosure level and leverage.

However, a negative association between leverage and disclosure level is also expected (Wallace et al., 1994; Eng and Mak, 2003). As mentioned above, leverage can reduce the free cash flow problem and act as a monitoring mechanism to the managershareholder relation. In addition, bondholders can mitigate agency costs of debt through bond covenants rather than increased disclosure in annual reports (Jensen, 1986). Consequently, the need for voluntary disclosure can be substituted by the presence of debt. In sum, the results of previous studies are mixed and hence no directional relation between leverage and disclosure level can be conjectured. Leverage (LEVERAGE) is measured as the ratio of total debt to common equity.

\subsubsection{Profitability}

Several studies show the existence of a positive relation between profitability and corporate disclosure. Agency theory suggests that managers of more profitable firms are more likely to disclose additional information to support the continuance of their positions and compensation (Singhvi and Desai, 1971). According to signaling theory, Ng and Koh (1994) argue that highly profitable firms are more visible to the public and subject to greater public scrutiny, prompting greater disclosure by these firms to avoid external regulation. However, Wallace and Naser (1995) report a significant negative relation between profitability and disclosure level. Given that the empirical evidence on the effect of profitability on the extent of corporate disclosure is mixed, no directional relation is expected. Profitability (ROA) is proxied by firm return on assets computed as the ratio of earnings before extraordinary items divided by total assets.

\subsubsection{Audit firm size}

For a host of reasons, audit firm size is likely to be positively associated with disclosure level. First, agency theory suggests that high quality audits may mitigate agency conflict between managers and shareholders. Large audit firms are more likely to be independent, and hence they can constrain managers to make more informative disclosure, that is, to conform to the standards (DeAngelo, 1981). Second, big auditors may induce 
companies to enhance the quality and credibility of information presented in their annual reports to preserve their reputations (Firth, 1979). Finally, signaling theory may also explain the relation between auditor size and disclosure. Managers that hire large auditors may signal to the market their willingness to disclose high quality information (Healy and Palepu, 2001). Overall, we expect a positive relation between audit firm size and disclosure level. We control for audit firm size by introducing a dummy variable (BIG4) equal to 1 if the firm's accountants are certified by at least one Big Four accounting firm, and zero otherwise.

\subsubsection{Analyst following}

Prior studies on disclosure examine the relation between analyst following and corporate disclosure (e.g., Lang and Lundholm, 1993). Analyst following can explain the level of disclosure by companies. Since firms with greater analyst following face greater demand for information by analysts, they are more likely to disclose additional information. It is expected that the extent of voluntary disclosure increases with the number of analysts following the firm. We measure analyst following (ANALYST) as the number of analysts following the firm in year $\mathrm{t}$.

\subsubsection{Cross-listing}

Several studies document a positive association between cross-listing and disclosure level (Wallace et al., 1994; Raffournier, 1995). Firms with foreign listings face additional capital market pressures, thus they must comply with foreign capital market rules concerning the additional information required in their annual reports. In addition, foreign investors are more stringent about the monitoring of management and require additional information to mitigate the information asymmetry between managers and external shareholders. According to the capital need hypothesis, Cooke (1992) suggests that firms listed on foreign markets face higher competition for capital with domestically listed enterprises. Consequently, they have greater incentives to disclose information to enhance their transparency, and hence raise capital at lower costs. As a result, we expect that cross-listed firms exhibit greater voluntary disclosure. To control for cross-listing, we introduce a dummy variable (XLIST) that takes the value 1 if the firm's shares are traded on foreign markets, and zero otherwise.

\subsubsection{Liquidity}

Prior research suggests that liquidity ratios may determine the disclosure levels in annual reports (Cooke 1989 a,b). Liquidity ratios are used to assess the financial soundness of 
a firm. The higher the ratio, the greater the ability of a firm to meet its current obligations, hence, the more likely it is to disclose additional information to signal its better performance. On the other hand, it has also been argued that firms with weak liquidity ratios have greater incentive to disclose more information, to give additional details about their weak performance and to reassure investors (Wallace et al., 1994). Another line of support for this negative relation comes from the agency theory prediction. Agency costs increase with the proportion of debt in a firm's capital structure, suggesting that the higher the liquidity ratio, the lower the proportion of debt, and hence firms need less disclosure to mitigate agency costs of debt. Overall, given the mixed results documented in prior research, no directional relation is expected. Liquidity (LIQUIDITY) is measured as the ratio of current assets to current liabilities.

\subsubsection{Market-to-book ratio}

Market-to-book ratio is shown in previous research as a determinant of the extent of voluntary disclosure. It is commonly used to proxy for the investment opportunity set and the associated information asymmetry between management and investors. Nagar et al., (2003) document a positive association between market-to-book ratio and disclosure level, explaining the effectiveness of disclosure in mitigating the greater information asymmetry in high market-to-book ratio firms. Hence, there may be greater disclosure in high market-tobook ratio firms. Market-to-book ratio $(M B)$ is measured as the market value of equity divided by the book value of equity.

\subsubsection{Security issuance}

Several studies provide evidence that a firm's external financing need determines its level of voluntary disclosure. Frankel, McNichols and Wilson (1995) find that firms raising external funds have greater incentives to make voluntary disclosures. In another study, Lang and Lundholm (1993) show that analyst ratings of disclosures increase with the possibility that firms issue securities in the current or future periods. Since the lack of information prior to raising external capital may be interpreted as a bad signal, managers are more likely to disclose all information available, to benefit from cheaper external financing. Lang and Lundholm (2000) show evidence that firms that make equity offerings increase their disclosure activity six months before the offering to reduce their cost of capital. These findings suggest that debt and equity offerings are positively associated with the extent of voluntary disclosure. Hence, we expect that voluntary disclosure increases with the need for 
external financing. We control for firms' external financing motivation using a dummy variable (ISSUE) which equals one if the firm issues debt or equity securities in year t or the two years following year $t$, and zero otherwise.

\subsubsection{Industry dummies}

It has been argued that levels of disclosure in corporate annual reports are not likely to be identical throughout all sectors of the economy. Indeed, some industries are more likely to disclose additional information than others, for a number of reasons. For instance, Cooke (1989) reports historical reasons for differences in the level of disclosure for Swedish companies. Cooke (1992) finds that the difference in disclosure level between Japanese manufacturing firms and non-manufacturing firms is due to the economic importance of this sector in the economy. Proprietary costs and accounting quality may also constitute industryspecific factors that determine the level of disclosure across industries. In sum, we introduce industry dummies in the regressions to control for potential differences in disclosure levels across industries. Industries are identified using the Campbell (1996) classification.

\subsubsection{Year dummies}

We introduce year dummies in all regressions of our model to control for time effects that manifest in changes in macroeconomic conditions, which in turn influence firm voluntary disclosure decisions.

Appendix 2 summarizes the definition of the variables used in the present study.

\subsection{Descriptive statistics and univariate analysis}

Table 1 (Panel A) displays characteristics of the sample firms and shows their distributions across industries using the Campbell (1996) grouping. Three industries dominate the sample: services (0.30), consumer durables (0.1769), and capital goods (0.1038).

Descriptive statistics of our study variables are reported in Table 1 (Panel B). The average (median) percentage of the total voluntarily disclosed items, DSCORE, is 0.39 (0.41), with a wide range from a minimum of 0.04 to a maximum of 0.70 . The standard deviation of DSCORE is 0.13. The mean (median) of GSCORE and FSCORE are $0.42(0.42)$ and 0.31 
(0.33), respectively, with a standard deviation of 0.15 for the governance information and 0.11 for the financial information. Overall, these results suggest that the sample firms present large variability with respect to governance information, financial information, and the total disclosure index. Table 1 (Panel B) also provides descriptive statistics on the independent variables. The mean (median) distance from a firm's headquarters to the Paris region is 195.27 (26.25) kilometers with standard deviation of 224.45 kilometers. The mean (median) of road distance is 234.67 (34.50) kilometers with standard deviation of 271.09 kilometers, implying large variation in these two measures of geographic distance.

[Insert Table 1about here]

Table 2 reports Pearson and Spearman correlations between voluntary disclosure score, geographic location measures, and control variables. There is a strong association between our disclosure score and different measures of distance between corporate headquarters and the Paris region. We find that the variables DISTANCE, ROAD DISTANCE, and OUTSIDE_PARIS are highly positively associated with the voluntary disclosure score, thus supporting our prediction of a positive location effect on voluntary disclosure. The analysis also shows that disclosure score is positively associated with firm size, leverage, profitability, audit firm size, analyst following, cross-listing, and security issuance, and negatively associated with firm liquidity. These results are consistent with prior research on voluntary disclosure, as discussed in Ahmed and Courtis (1999), and hence support our measure of voluntary disclosure.

\section{[Insert Table 2 about here]}

Examining Table 2, we note that multicollinearity is not a serious concern, since the correlation coefficients between the independent variables are small except for the three geographic location measures. This result does not constitute a problem, because we introduce these variables one by one in the estimation regressions. An alternative way to test for multicollinearity is to compute the variance inflation factor (VIF). We find that the VIFs for all independent variables in our baseline model are below the rule of thumb threshold of 10 (Chatterjee and Hadi, 2006). Consequently, we argue that multicollinearity is not a serious concern and that the empirical analysis can be interpreted with greater confidence.

Table 3 reports mean comparison tests of the level of voluntary disclosure between two groups of firms separated each time according to their distance to the Paris region and 
firm characteristics. The initial sample is partitioned into two groups based on firm location and firm characteristics: whether a firm is outside or inside the Paris region (variable OUTSIDE_PARIS); whether a firm's distance to the Paris region is above or below median levels (variable DISTANCE_D); whether a firm's road distance to the Paris region is above or below the median level (variable ROADDISTANCE_D); and finally whether firm characteristics are above or below their median levels. We find that voluntary disclosure is higher for firms located outside the Paris region compared with those inside the Paris region (mean 0.4085 versus 0.3815 ). We also document that firms that are distant to the Paris region exhibit higher levels of voluntary disclosure in their annual reports than their nearby counterparts (a mean of 0.4088 versus 0.3812 ). We obtain similar results when we consider the road distance to the Paris region. Our interpretation is that voluntary disclosure by remotely located firms is important, since distant shareholders are more likely to face high oversight costs that can be limited by increasing information available to investors.

Table 3 also documents the importance of the control variables used in our analysis. In brief, the results indicate that voluntary disclosure is positively and significantly associated with firm size, leverage, audit firm size, cross-listing, market-to-book ratio, and security issuance variables, consistent with prior research. Although our results concerning the relation between voluntary disclosure and different geographic location proxies is consistent with our theoretical prediction, it is worth noting that multivariate analysis would provide additional insights into how the geographic distance to the Paris region determines voluntary disclosure by French listed firms.

\section{[Insert Table 3 about here]}

\section{Methodology and empirical results}

This section explains the methodology used to test our hypothesis of a positive association between the geographic distance to the Paris region and voluntary disclosure. We supplement the findings of the univariate analysis by running multivariate regressions. Finally, we extend our findings to cover a number of additional tests and robustness checks. 


\subsection{Baseline model specification}

To test our research hypothesis, we estimate the following model specification using a linear multiple Ordinary Least Squares (OLS) with standard errors that are adjusted for heteroskedasticity and clustered at the firm level:

$$
\begin{aligned}
& \text { DSCORE }=\beta_{0}+\beta_{1} *(\text { GEOGRAPHY })+\beta_{2} * \text { SIZE }+\beta_{3} * \text { LEVERAGE }+\beta_{4} * \text { ROA }+ \\
& \beta_{5} * \text { BIG }+\beta_{6} * \text { ANALYST }+\beta_{7} * \text { XLIST }+\beta_{8} * \text { LIQUIDITY }+\beta_{9} * M B+\beta_{10} * \\
& \text { ISSUE } \left.+\beta_{11} \text { (Industry Dummies }\right)+\beta_{12} *(\text { Year Dummies })+\varepsilon_{i}
\end{aligned}
$$

where GEOGRAPHY stands for each of the proxies of geographic location: distance in kilometers to the Paris region (DISTANCE); road distance in kilometers to the Paris region (ROAD DISTANCE); and a dummy variable that takes the value 1 if the firm is located outside the Paris region, and zero otherwise (OUTSIDE_PARIS). These variables are introduced one by one in the model. The multivariate regression also controls for firm characteristics that are potentially correlated with voluntary disclosure, as documented in previous research. We control for firm size, leverage, profitability, audit firm size, analyst following, cross-listing, liquidity, market-to-book ratio, and security issuance. Industry dummies are included in the model, since voluntary disclosure varies from one industry to another (Wallace et al., 1994). Finally, we introduce year dummies to address time trend effects that can influence firm voluntary disclosure policies.

\subsection{Multivariate analysis}

Table 4 reports the results of the effect of geography on the extent of voluntary disclosure. For each of the distance variable tests, we run three regressions in which we use the total disclosure score and its two subgroups as the dependent variable.

[Insert Table 4 about here]

Columns 1-3 concern the regressions using the variable DISTANCE as the geographic location proxy. We find that DISTANCE is strongly associated with the total disclosure score and its two subcategories (positive and significant at the 0.01 level), supporting the prediction of our hypothesis that firms located far away from the Paris region have higher levels of voluntary disclosure. 
We find similar results in columns 4-6 by using ROAD DISTANCE to the Paris region as a proxy for geographic location. The coefficient of the variable ROAD DISTANCE is also positive and significant at the 0.01 level. Hence, the distance between a firm's headquarters and the Paris region seems to positively affect the level of voluntary disclosure in annual reports. These findings suggest that firms tend to disclose more information when they are located far from France's major metropolitan areas. This result is consistent with the view that geographic distance is associated with higher monitoring costs, thereby leading firms located in remote areas to voluntarily disclose more information to make managerial actions more observable.

Finally, we introduce a dummy variable OUTSIDE_PARIS, which takes the value 1 if the firm is located outside the Paris region, and zero otherwise. The results are reported in columns 7-9 for total disclosure score, the governance information subgroup, and the financial information subgroup, respectively. We continue to find supporting evidence at the 1\% level for the prediction from our hypothesis that remotely located firms use more voluntary disclosure to improve information available to distant investors. The variable OUTSIDE_PARIS also exhibits positive coefficients (0.0494, 0.0497, and 0.0422) for the total disclosure score, the governance information subgroup, and the financial information subgroup, respectively; all are statistically significant at the 0.01 level.

In summary, the results reported in Table 4 are consistent with our prediction that firms located far from the Paris region incur higher monitoring costs because the observability of managerial investment decisions decreases with distance. Hence, remote firms provide more voluntary disclosure in their annual reports to reduce monitoring costs and attract potential investors, who are most often located in the Paris region. Alternatively, proximity to metropolitan areas seems to lower the need for voluntary disclosure, because most investors are located in metropolitan areas and can oversee and monitor nearby companies at lower cost.

Turning to the effect of control variables on voluntary disclosure level, Table 4 shows that all control variables are significant, with their predicted signs except for two variables, ROA and LIQUIDITY. The variable SIZE is positively and significantly associated with total disclosure score, as well as with the disclosure of information subgroups. The variables BIG4, XLIST, MB, and ISSUE exhibit positive and statistically significant (at the 
0.01 level) signs, suggesting that firms increase their disclosure level, respectively, when they are audited by Big Four companies, when they are listed on foreign stock exchanges, when they have high growth opportunities, and when they need external capital. These results are consistent with our predictions in the first section and with most prior research on voluntary disclosure (e.g., Ahmed and Courtis, 1999).

The total voluntary disclosure score, DSCORE, is also positively and significantly (at the 0.10 level) associated with ANALYST, suggesting that companies that are followed by a greater number of analysts disclose more information in their annual reports to meet the information needs of those analysts. LEVERAGE is negative and significant at the 0.01 level for all regressions presented in Table 4, supporting the prediction that leverage may act as a monitoring mechanism substituting for the role of voluntary disclosure. Moreover, we find that LIQUIDITY is negative and statistically significant (at the 0.01 level) for the financial information score, FSCORE, in all regressions, but it is not significant for the governance information score, GSCORE, and the overall disclosure score, DSCORE, In sum, the results on the control variables are consistent with the prior findings of disclosure studies, which document that mixed results may be explained by differences in the construction of the disclosure index, differences in the definition of the explanatory variables, and differences in research design (Ahmed and Courtis, 1999).

The adjusted $R^{2}$ for the level of overall disclosure is about 0.27. As for the information subgroups, the adjusted $R^{2}$ ranges from 0.24 for governance information to 0.14 for financial information. Hence, these values suggest that the regression models explain the variation in voluntary disclosures not only for the total score, but also for the information subgroups. Overall, the multivariate analysis offers additional insights into the effect of geographic location on voluntary disclosure level, and supports the prediction of our hypothesis that voluntary disclosure increases with distance to the Paris region.

\subsection{Additional tests and robustness checks}

To further explore the validity of our hypothesis of a positive relation between geographic location and voluntary disclosure, we perform a series of sensitivity tests consistent with those documented in the literature. Notably, we employ alternative measures of the dependent and independent variables. We also use alternative statistical approaches. 


\subsubsection{Alternative measures of the dependent variable}

The dependent variables in our model are the total voluntary disclosure index, DSCORE, and its two subgroups, GSCORE and FSCORE. We follow prior research on disclosure and examine the nature of the data. It is argued that any research using selfconstructed disclosure indexes should be aware of the data structure, and hence it needs to examine the effects of potential non-normality of the data (Cooke, 1989). Thus, we perform a Jarque and Bera (1980) test of normality. This test rejects, in our case, the normality of the total disclosure score and its two subgroups. We then perform a natural logarithm transformation to these scores to meet the OLS assumptions by bringing the residuals of the regression closer to a normal distribution.

Table 5 displays the results of the regressions using the natural logarithm of the disclosure scores as the dependent variable. We provide further evidence on the positive association between the different proxies of geographic location and voluntary disclosure level. As for the control variables, we also find results similar to those in previous regressions, except for ANALYST, which becomes not statistically significant, and LIQUIDITY, which becomes statistically significant.

\section{[Insert Table 5 about here]}

Second, compared to the Botosan (1997) checklist over a single industry, our sample spans 10 industries. Thus, we proxy for our dependent variables using industry-adjusted disclosure scores to take into account the industry-specific effects, such as proprietary costs, on disclosure level. The disclosure scores are industry-adjusted by computing the average disclosure score for each industry and then subtracting the industry average score from the initial score for each firm. ADSCORE is the adjusted overall disclosure score, $A D G O V$ is the industry-adjusted governance score, and $A D F I N$ is the adjusted financial score. Table 6 displays the results of the regressions using industry-adjusted scores as the dependent variable. We find that the location effect is always positive and statistically significant at better than the 0.01 level. All control variables have the same signs as our baseline model except for LIQUIDITY, which becomes statistically significant. 


\subsubsection{Alternative geographic location proxies}

In this section, we run additional tests to analyze whether our results hinge on the geographic location proxies. We use two alternative proxies for distance: DISTANCE100, defined as a dummy variable that equals one if the firm is located more than 100 kilometers from the Paris region, and zero otherwise (columns 1-3); and DISTANCE250, defined as a dummy variable that equals one if the firm is located more than 250 kilometers from the Paris region, and zero otherwise (columns 4-6).

Table 7 displays the results of the regressions using these two alternative geographic location proxies. We find that the coefficients on the geographic measures continue to exhibit a positive and statistically significant (at the 0.01 level) relation between geography and voluntary disclosure. This result reinforces that the link between firm location and voluntary disclosure level is not driven by how we gauge distance. All control variables have the same signs as in the baseline model. Overall, our results are robust to alternative measures of geographic location.

\subsubsection{Alternative statistical approaches}

We perform additional tests to verify the robustness of our results. First, the Fama and MacBeth (1973) estimation method is used to control for potential cross-sectional dependence in the data, which might yield biased estimates of standard errors, and hence can increase the risk of incorrect statistical inferences. This method consists of two steps. First, for each single time-period, a cross-sectional regression is performed. Second, the final coefficient estimates are obtained as the average of the first-step coefficient estimates.

The regression results are reported in columns $1-3$ of Table 8 . We further find that the impact of firm geographic location on voluntary disclosure level is persistently positive and statistically significant at the 0.01 level. Similarly, we estimate our model using the FamaMacBeth with Newey-West standard errors (columns 4-6). This approach is designed to account for serial autocorrelation using a first order autoregressive process (Petersen, 2009). Our findings are largely consistent with our prediction that distant firms provide more voluntary disclosure in their annual reports to increase information available to investors and thus reduce management monitoring costs. 
Further, we estimate a random effects regression that permits us to exploit the panel structure of the data and allows for time-invariant geographic variables (columns 7-9). We find again a strong positive relation between geographic location and disclosure level in annual reports. We also note that the control variables have similar signs as in the baseline model.

\section{Conclusion}

Recently, a new economic geography literature has focused on the impact of a firm's geographic location on its financial behavior (e.g., Loughran, 2008; Almazan et al., 2010; John et al., 2011). On the one hand, it has been argued that distance adversely affects investors' ability to monitor managerial investment decisions in remotely located firms, which exacerbates monitoring costs by outside investors in these firms. On the other hand, the voluntary disclosure literature documents a strong link between agency costs and a firm's voluntary disclosure decisions. Consistent with the agency theory prediction, voluntary disclosure mitigates the agency problem between insiders and external shareholders by providing these shareholders with information that contributes in reducing management oversight costs (Jensen and Meckling, 1976). This study brings these two literatures together and examines how a firm's geographic location affects its voluntary disclosure policy within the agency theory framework.

Using a sample of 1,040 firm-year observations over the period 2007 to 2010, we examine the impact of a firm's geographic location on the extent of voluntary disclosure in the annual reports of French listed firms. To measure the level of voluntary disclosure of our sample firms, we use a self-constructed index based on prior voluntary disclosure studies. We control for firm size, leverage, profitability, audit firm size, analyst following, cross-listing, liquidity, market-to-book ratio, and security issuance. We posit that decreased observability of managerial actions in remotely located firms leads to high oversight costs for outside investors and predict that remote firms are more likely to make voluntary disclosure as a way to reduce these costs. Consistent with our expectation, we find that as distance to the Paris region increases, corporate insiders are more willing to disclose information that allows a better understanding of their performance given that external monitoring of remote locations is too costly for outside shareholders. Our results are robust to alternative measures of 
voluntary disclosure, to several geographic location proxies, and to a variety of alternative statistical approaches. 


\section{References}

Abdulkadir, M., Schwienbacher, A., 2016. Voluntary disclosure of corporate venture capital investments. Journal of Banking \& Finance 68, 69-83.

Ahmed, K., Courtis, J.K., 1999. Associations between corporate characteristics and disclosure levels in annual reports: A meta-analysis. British Accounting Review 31, 35-61.

Ali, A., Chen, T., Radhakrishnan, S., 2007. Corporate disclosures by family firms. Journal of Accounting and Economics 44, 238-286.

Almazan, A., De Motta, A., Titman, S., Uysal, V., 2010. Financial structure, acquisition opportunities, and firm locations. The Journal of Finance 65, 529-563.

Ayers, B.C., Ramalingegowda, S., Yeung, E., 2011. Hometown advantage: the effects of monitoring institution location on financial reporting discretion. Journal of Accounting and Economics 52, 41-61.

Botosan, C. A.,1997. Disclosure level and the cost of capital. The Accounting Review 72, 323-349.

Boubakri, N., Guedhami, O., Saffar., W. 2016. Geographic location, foreign ownership, and cost of equity capital: Evidence from privatization. Journal of Corporate Finance 38, 363381.

Boubaker, S., Derouiche, D., Lasfer, M., 2015. Geographic location, excess control rights, and cash holdings. International Review of Financial Analysis 42, 24-37.

Boubaker, S., Mansali, H., Rjiba, H. 2014. Large controlling shareholders and stock price synchronicity. Journal of Banking and Finance 40, 80-96.

Campbell, J., 1996. Understanding risk and return. Journal of Political Economy 104, 298345.

Chatterjee, S., Hadi, A.S., 2006. Regression analysis by example. John Wiley and Sons.

Chau, G. K., Gray, S. J., 2002. Ownership structure and corporate voluntary disclosure in Hong Kong and Singapore. The International Journal of Accounting 37, 247-265.

Chen, H., Gompers, P., Kovner, A., Lerner, J., 2010. Buy local? The geography of venture capital. Journal of Urban Economics 67, 90-102.

Chen, S., Chen, X., Cheng, Q., 2008. Do family firms provide more or less voluntary disclosure? Journal of accounting research 46, 499-536.

Cheng, E. C. M., Courtenay, S. M., 2006. Board composition, regulatory regime and voluntary disclosure. The International Journal of Accounting 41, 262-289.

Chhaochharia, V., Kumar, A., Niessen-Ruenzi, A., 2012. Local investors and corporate governance. Journal of Accounting and Economics 54, 42-67.

Cooke, T.E., 1989. Regression analysis in accounting disclosure studies. Accounting Business Research 28, 209-224.

Cooke, T.E., 1989a. Disclosure in the corporate annual report of Swedish companies. Accounting and Business Research 19, 113-122.

Cooke, T.E., 1989b. Voluntary corporate disclosure by Swedish companies. Journal of International Financial Management and Accounting 1,171-195. 
Cooke, T.E., 1992. The effect of size, stock market listing and industry type on disclosure in the annual reports of Japanese listed corporations. Accounting and Business Research 22, 229-237.

Coval, J. D., Moskowitz, T. J., 2001. The geography of investment: Informed trading and asset prices. Journal of Political Economy 4, 811-841.

Coval, J.D., Moskowitz, T.J., 1999. Home bias at home: Local equity preference in domestic portfolios. The Journal of Finance 54, 2045-2073.

Cronbach, L., 1951. Coefficient alpha and internal structure of tests. Psychometrica 16, 297334.

Davis, J.C., Henderson, J.V., 2008. The agglomeration of headquarters. Regional Science and Urban Economics 38, 445-460.

DeAngelo, L., 1981. Auditor size and audit quality. Journal of Accounting and Economics 3, 189-199.

Di Mento, J., 2009. Stent (or Dagger?) in the heart of town: Urban freeways in syracuse, 1944-1967. Journal of Planning History 8, 133-161.

El ghoul, S., Guedhami, O., Ni, Y., Pittman, J., Saadi, S., 2012. Does information asymmetry matter to equity pricing? Evidence from firm's geographic location. Contemporary Accounting Research 30, 140-181.

Eng, L. L., Mak, Y. T., 2003. Corporate governance and voluntary disclosure. Journal of Accounting and Public Policy 4, 325-345.

Faccio, M., Lang, L., 2002. The ultimate ownership of Western European corporations. Journal of Financial Economics 65, 365-395.

Fama, E. F., MacBeth. J. D., 1973. Risk, return, and equilibrium: Empirical tests. Journal of Political Economy 81, 607-636.

Firth, M., 1979. The effect of size, stock market listings, and auditors on voluntary disclosure in corporate annual reports. Accounting and Business Research 9, 273-280.

Frankel, R., McNichols, M., Wilson, G., 1995. Discretionary disclosure and external financing. The Accounting Review 70, 135-150.

Gaspar, J.M., Massa, M., 2007. Local Ownership as private information: Evidence on the monitoring-liquidity trade-off. Journal of Financial Economics 83, 751-792.

Guillain, R., Le Gallo, J., 2010. Agglomeration and dispersion of economic activities in and around Paris: an exploratory spatial data analysis. Environment and Planning B: Planning and Design 37, 961-981.

Gul, F.A., Leung, S., 2004. Board leadership, outside directors' expertise and voluntary corporate disclosure. Journal of Accounting and Public Policy 23, 351-379.

Halbert, L., 2004. The intrametropolitan decentralization of business services in the Paris region: Patterns, interpretation, consequences. Economic Geography 80, 381-405

Hau, H. 2001. Location matters: An examination of trading profits. The Journal of Finance 5, 1959-1983.

Healy, P., Hutton, A., Palepu, K., 1999. Stock performance and intermediation changes surrounding sustained increases in disclosure. Contemporary Accounting Research 16, 485520. 
Healy, P.M., Palepu, K.G., 2001. Information asymmetry, corporate disclosure, and the capital markets: A review of the empirical disclosure literature. Journal of Accounting and Economics 31, 405-440.

Hollander, S., Verriest, A., 2016. Bridging the gap: The design of bank loan contracts and distance, Journal of Financial Economics 119, 399-419.

Ivkovic', Z., Weisbenner, S., 2005. Local does as local is: Information content of the geography of individual investors' common stock investments. The Journal of Finance 1, 267-306.

Jarque, C.M., Bera, A.K., 1980. Efficient tests for normality, homoscedasticity and serial independence of regression residuals. Economics Letters 6 (3), 255-259.

Jensen, M.C., 1986. Agency costs of free cash flow corporate finance and takeovers. American Economic Review 76, 323-329.

Jensen, M.C., Meckling, W.H., 1976. Theory of the firm, managerial behavior, agency cost and ownership structure. Journal of Financial Economics 3, 305-61.

John, K., Knyazeva, A., Knyazeva, D., 2011. Does geography matter? Firm location and corporate payout policy. Journal of Financial Economics 101, 533-551.

Kang, J. K., Kim, J. M., 2008. The geography of block acquisitions. The Journal of Finance 63, 2817-2858.

Karamanou, I., Vafeas, N., 2005. The association between corporate boards, audit committees, and management earnings forecasts: An empirical analysis. Journal of Accounting Research 43, 453-486.

Kedia, S., Panchapagesan, V., Uysal, V., 2008. Geography and acquirer returns. Journal of Financial Intermediation 17, 256-275.

Landier, A., Nair, V., Wulf, J., 2009. Trade-offs in staying close: Corporate decision making and geographic dispersion. The Review of Financial Studies 22, 1119-1148.

Lang, M., Lundholm, R., 1993. Cross-sectional determinants of analysts' ratings of corporate disclosures. Journal of Accounting Research 31, 246-271.

Lang, M., Lundholm, R., 1996. Corporate disclosure policy and analyst behavior. The Accounting Review 71, 467-493.

Lang, M., Lundholm, R., 2000. Voluntary disclosure and equity offerings: reducing information asymmetry or hyping the stock? Contemporary Accounting Research 17, 623662.

Li, M., Zhao, X. 2016. Neighborhood effect on stock price comovement. North American Journal of Economics and Finance 35, 1-22.

Loughran, T., 2008. The impact of firm location on equity issuance. Financial Management 37, 1-21.

Malloy, C. J., 2005. The geography of equity analysis. The Journal of Finance 2, 719-755.

Meek, G. K., Roberts, C. B., Gray, S. J., 1995. Factors influencing voluntary annual report disclosures by US and UK and continental European multinational corporations. Journal of International Business Studies 26, 555-572.

Mian, A., 2006. Distance Constraints: The limits of foreign lending in poor economies. The Journal of Finance 61, 1465-1505. 
Nagar, V., Nandab, D., Wysockic, P., 2003. Discretionary disclosure and stock-based incentives. Journal of Accounting and Economics. 34, 283-309

Ng, E.J., Koh, H.C., 1994. An agency theory and probit analytic approach to corporate nonmandatory disclosure compliance. Asia-Pacific Journal of Accounting 1, 29-44.

O'Brien, P. C., Tan, H. 2015. Geographic proximity and analyst coverage decisions: Evidence from IPOs. Journal of Accounting and Economics 59, 41-59.

Peterson, M.A., 2009. Estimating standard errors in finance panel data sets: comparing approaches. The Review of Financial Studies 22, 435-480

Petersen, M.A., Rajan, R.G., 2002. Does distance still matter? The information revolution in small business lending. The journal of Finance 57, 2533-2570.

Pirinsky, C., Wang, Q., 2006. Does corporate headquarters location matter for stock returns? The Journal of Finance 61, 1991-2015.

Raffournier, B., 1995. The determinants of voluntary financial disclosure by Swiss listed companies. The European Accounting Review 4, 261-280.

Shaw, K.W., 2003. Corporate disclosure quality, earnings smoothing, and earnings' timeliness. Journal of Business Research 56, 1043- 1050.

Singhvi, S.S., Desai, H.B., 1971. An empirical analysis of the quality of the corporate financial disclosure. The Accounting Review 46, 120-138.

Tian, X., 2011. The causes and consequences of venture capital stage financing. Journal of Financial Economics 101, 132-159.

Wallace, R.S.O., Naser, K., Mora, A., 1994. The relationship between comprehensiveness of corporate annual reports and firm characteristics in Spain. Accounting and Business Research 25, 41-53.

Wallace, R.S.O., Naser, K., 1995. Firm-specific determinants of comprehensiveness of mandatory disclosure in the corporate annual reports of firms on the stock exchange of Hong Kong. Journal of Accounting and Public Policy 14, 311-368.

Watts, R. L., Zimmerman, J.L., 1986. Positive accounting theory. Prentice Hall, Englewood Cliffs, NJ. 


\section{Appendix 1. Voluntary disclosure checklist}

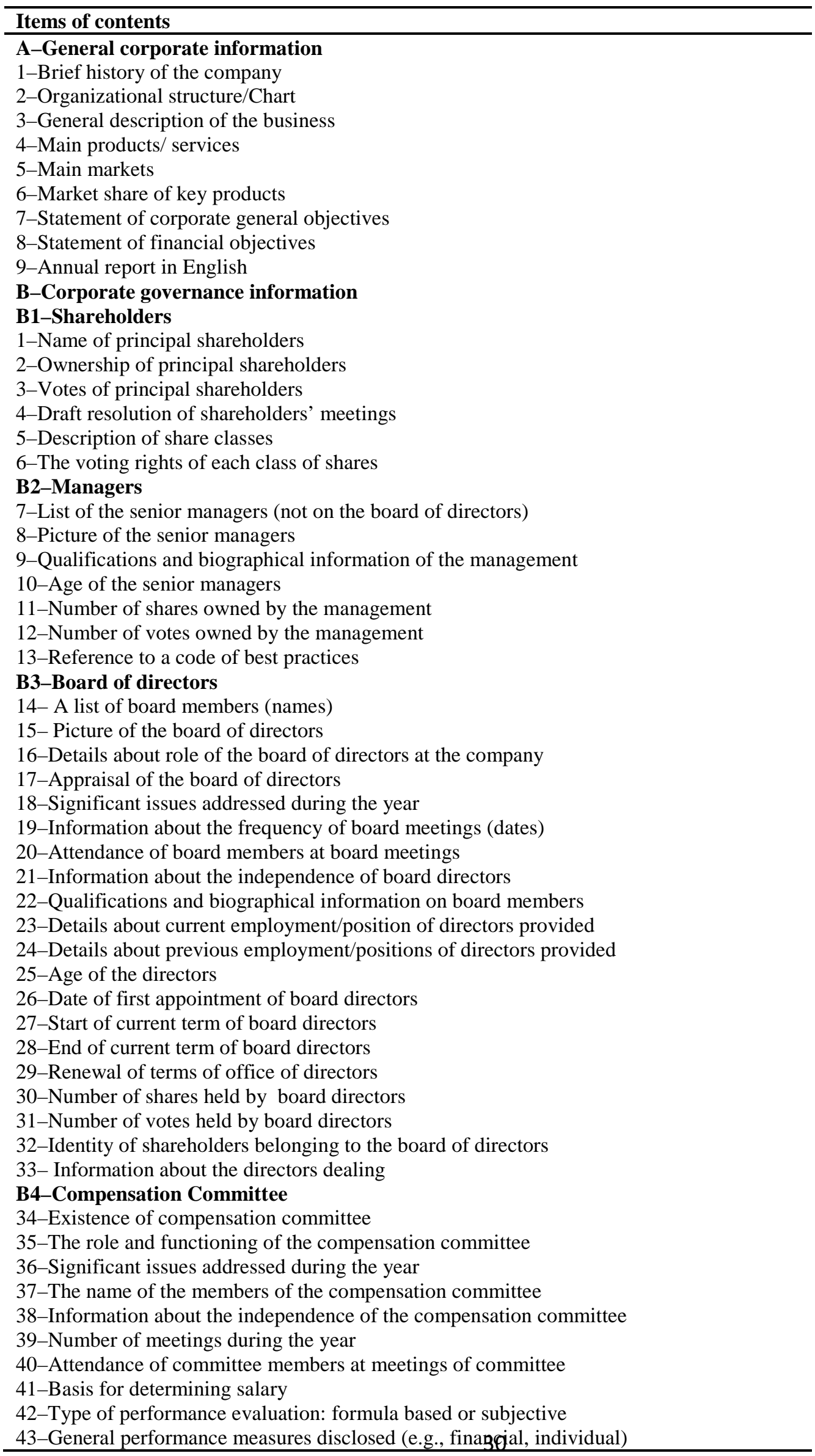


44-Specific performance measures disclosed (e.g., ROA, Operating income)

45-Weight assigned on performance measures

46-Discuss the decision-making process of directors' pay

47-Specifics of directors' salaries disclosed (numbers)

48-Form of directors' salaries disclosed (cash, shares, etc.)

49-Discuss the decision-making process of managers' (not on board) pay

50-Numbers of managers' (not on board) salaries disclosed

51-Form of managers' (not on board) salaries disclosed

52-Information about stock option programs

\section{B5-Audit committee}

53-Existence of an audit committee

54-The role and functioning of the audit committee

$55-$ Significant issues addressed during the year

56-The names and qualifications of the audit committee members

57-Statement on independence

58-Number of committee meetings

59-Attendance at committee meetings

60 -Other internal audit functions besides audit committee

\section{B6-External Audit}

61-The names of the auditing firms

62-Date of appointment of current auditors

63-Expiration date of term

64-Information about renewal of terms

65-Auditors' remuneration

\section{C-Financial information}

C1-Accounting information

1-Balance sheet of past 2 years

2-Cash flow statement of past 2 years

3-Turnover of past 2 years

4-Sales of key products

5-Summary of financial data of previous years

6-Summary of key ratios over at least three years

7-Dividend policy

8-Earnings per share

9-Audit or report

10-Financial calendar

C2-Stock price information

11-Historical share prices

12-Current share price

13-Share prices trend

14-Stock price performance in relation to stock market index

15-Market capitalization at year end

16-Trend of market capitalization

17-Foreign stock market listing information

\section{C3-Forward-looking information}

18-Sales forecast

19-Forecasted market share

20-Cash flow/Turnover forecast

21-Earning estimates 


\begin{tabular}{|c|c|}
\hline Variables & Definitions \\
\hline \multicolumn{2}{|c|}{ Panel A: Variables used in the baseline model } \\
\hline DSCORE & $\begin{array}{l}\text { The total disclosure score computed as the total information disclosed/ maximum } \\
\text { possible information score for each firm. }\end{array}$ \\
\hline GSCORE & $\begin{array}{l}\text { The governance score computed as the total governance information disclosed/ } \\
\text { maximum possible governance information score for each firm. }\end{array}$ \\
\hline FSCORE & $\begin{array}{l}\text { The financial score computed as the total financial information disclosed/ maximum } \\
\text { possible financial information score for each firm. }\end{array}$ \\
\hline DISTANCE & Logarithm of one plus distance in kilometers to the Paris region. \\
\hline ROAD DISTANCE & Logarithm of one plus road distance in kilometers to the Paris region. \\
\hline OUTSIDE_PARIS & $\begin{array}{l}\text { Dummy variable that takes the value } 1 \text { if the firm is located outside the Paris region and } \\
\text { zero otherwise. }\end{array}$ \\
\hline SIZE & Firm size measured as the natural logarithm of firm total assets in euros. \\
\hline LEVERAGE & Leverage is calculated as the ratio of total debt to common equity. \\
\hline ROA & $\begin{array}{l}\text { Firm profitability calculated as the ratio of income before extraordinary items divided by } \\
\text { total assets (Return on assets). }\end{array}$ \\
\hline BIG4 & $\begin{array}{l}\text { Dummy variable equals one if firm's accountants are certified by at least one Big Four } \\
\text { accounting firm, and zero otherwise. }\end{array}$ \\
\hline ANALYST & Number of analysts following the firm. \\
\hline XLIST & $\begin{array}{l}\text { Dummy variable equals one if the firm's shares are traded on foreign markets, and zero } \\
\text { otherwise. }\end{array}$ \\
\hline LIQUIDITY & Liquidity measured as the ratio of current assets over current liabilities. \\
\hline MB & $\begin{array}{l}\text { MB is firm growth measured as the ratio of market value of equity to book value of } \\
\text { equity. }\end{array}$ \\
\hline ISSUE & $\begin{array}{l}\text { Dummy variable equals one if the firm issues debt or equity securities in the year t or the } \\
\text { two years following year } t \text {, and zero otherwise. }\end{array}$ \\
\hline \multicolumn{2}{|c|}{ Panel B: Robustness check variables } \\
\hline LNDSCORE & The natural logarithm of the total disclosure score. \\
\hline LNFIN & The natural logarithm of the governance disclosure score. \\
\hline LNGOV & The natural logarithm of the financial disclosure score. \\
\hline ADSCORE & $\begin{array}{l}\text { The industry-adjusted total disclosure score computed as the total score for each firm } \\
\text { minus the average total score for its industry. }\end{array}$ \\
\hline ADGOV & $\begin{array}{l}\text { The industry-adjusted governance disclosure score computed as the governance score } \\
\text { for each firm minus the average governance score for its industry. }\end{array}$ \\
\hline ADFIN & $\begin{array}{l}\text { The industry-adjusted financial disclosure score computed as the financial score for each } \\
\text { firm minus the average financial score for its industry. }\end{array}$ \\
\hline DISTANCE100 & $\begin{array}{l}\text { Dummy variable that equals one if the firm is located more than } 100 \text { kilometers to the } \\
\text { Paris region, and zero otherwise. }\end{array}$ \\
\hline DISTANCE250 & $\begin{array}{l}\text { Dummy variable that equals one if the firm is located more than } 250 \text { kilometers to the } \\
\text { Paris region, and zero otherwise. }\end{array}$ \\
\hline
\end{tabular}


Table 1. Sample description

Panel A. Industry classification of the sample firms using Campbell’s (1996) classification

\begin{tabular}{llcc}
\hline Industry & SIC code & Number of firms & Percentage \\
\hline Petroleum & 13,29 & 0 & 0 \\
Consumer durables & $25,30,36,37,50,55,57$ & 46 & 17.69 \\
Basic industry & $10,12,14,24,26,28,33$ & 26 & 10 \\
Food and Tobacco & $1,2,9,20,21,54$ & 24 & 9.23 \\
Construction & $15,16,17,32,52$ & 6 & 2.31 \\
Capital goods & $34,35,38$ & 27 & 10.38 \\
Transportation & $40,41,42,44,45,47$ & 4 & 1.54 \\
Unregulated utilities & 46,48 & 9 & 3.46 \\
Textiles and trade & $22,23,31,51,53,56,59$ & 24 & 9.23 \\
Services & $72,73,75,76,80,82,87,89$ & 78 & 30 \\
Leisure & $27,58,70,78,79$ & 16 & 6.15 \\
\hline Total & & 260 & 100 \\
\hline
\end{tabular}

Panel B. Descriptive statistics

\begin{tabular}{|c|c|c|c|c|c|c|c|}
\hline Variable & Mean & $\begin{array}{l}\text { Standard } \\
\text { deviation }\end{array}$ & Minimum & $\begin{array}{l}\text { 25th } \\
\text { percentile }\end{array}$ & Median & $\begin{array}{l}\text { 75th } \\
\text { percentile }\end{array}$ & Maximum \\
\hline \multicolumn{8}{|l|}{ Dependent variable } \\
\hline DSCORE & 0.39 & 0.13 & 0.04 & 0.30 & 0.41 & 0.49 & 0.70 \\
\hline GSCORE & 0.42 & 0.15 & 0.05 & 0.31 & 0.42 & 0.52 & 0.80 \\
\hline FSCORE & 0.31 & 0.11 & 0.00 & 0.24 & 0.33 & 0.38 & 0.67 \\
\hline \multicolumn{8}{|l|}{ Location measures } \\
\hline DISTANCE(in kilometers) & 195.27 & 224.45 & 0.00 & 0.00 & 26.25 & 385.65 & 697.20 \\
\hline $\begin{array}{l}\text { ROAD DISTANCE(in } \\
\text { kilometers) }\end{array}$ & 234.67 & 271.09 & 0.00 & 0.00 & 34.50 & 462.00 & 943 \\
\hline OUTSIDE_PARIS & 0.48 & 0.50 & 0.00 & 0.00 & 0.00 & 1.00 & 1.00 \\
\hline \multicolumn{8}{|l|}{ Control variables } \\
\hline SIZE & 11.79 & 1.73 & 4.00 & 10.68 & 11.71 & 12.88 & 17.17 \\
\hline LEVERAGE & 1.40 & 18.32 & -7.55 & 0.13 & 0.41 & 0.89 & 585.99 \\
\hline$R O A$ & 2.13 & 16.55 & -292.71 & 0.63 & 3.84 & 6.82 & 64.81 \\
\hline BIG4 & 0.44 & 0.50 & 0.00 & 0.00 & 0.00 & 1.00 & 1.00 \\
\hline ANALYST & 4.91 & 4.18 & 0.00 & 1.00 & 4.00 & 8.00 & 26.00 \\
\hline XLIST & 0.02 & 0.14 & 0.00 & 0.00 & 0.00 & 0.00 & 1.00 \\
\hline LIQUIDITY & 1.71 & 1.36 & 0.30 & 1.06 & 1.37 & 1.86 & 9.94 \\
\hline$M B$ & 1.74 & 1.76 & -0.89 & 0.76 & 1.25 & 2.07 & 10.97 \\
\hline ISSUE & 0.12 & 0.32 & 0.00 & 0.00 & 0.00 & 0.00 & 1.00 \\
\hline
\end{tabular}

Notes: This table presents characteristics of the sampled firms showing their distributions across industries using Campbell's (1996) classification (Panel A). It also provides summary statistics of variables used in the study (Panel B). DSCORE is the total disclosure index computed as the ratio of the total number of items disclosed to the maximum possible score. GSCORE is the governance disclosure index computed as the ratio of the total number of items disclosed to the maximum obtainable score. FSCORE is the financial disclosure index computed as the ratio of the total number of items disclosed to the maximum obtainable score. DISTANCE is computed as the natural logarithm of one plus distance in kilometers to the Paris region. ROAD DISTANCE is natural logarithm of one plus road distance in kilometers to the Paris region. OUTSIDE_PARIS is a dummy variable which equals one if the firm is headquartered outside the Paris region, and zero otherwise. SIZE is computed as the natural logarithm of firm total assets. LEVERAGE is calculated as the ratio of total debt to common equity. $R O A$ is firm profitability measured as earnings before extraordinary item divided by total assets. BIG4 a dummy variable equals one if firm's accountants are certified by at least one BIG4 accounting firm, and zero otherwise. ANALYST computed as the number of analysts following the firm. XLIST a dummy variable that equals one if the firm's shares are traded on foreign markets, and zero otherwise. LIQUIDITY measured as the ratio of current assets over current liabilities. $M B$ is firm growth measured as the ratio of market value of equity to book value of equity. ISSUE a dummy variable equals one if the firm issues debt or equity securities in the year $t$ or the two years following year $t$, and zero otherwise. 


\begin{tabular}{|c|c|c|c|c|c|c|c|c|c|c|c|c|c|}
\hline & (1) & (2) & (3) & (4) & (5) & (6) & (7) & (8) & (9) & $(10)$ & (11) & (12) & (13) \\
\hline (1) DSCORE & & $0.095^{* * *}$ & $0.096 * * *$ & $0.082 * * *$ & $0.365^{* * *}$ & $0.131 * * *$ & $0.018 * * *$ & $0.118 * * *$ & $0.151^{* * *}$ & $0.162 * * *$ & -0.064 & $0.089 * * *$ & $0.179 * * *$ \\
\hline (2) DISTANCE & $0.120 * * *$ & & $0.994 * * *$ & $0.861^{* * *}$ & -0.027 & $0.074 * *$ & -0.010 & -0.025 & -0.034 & 0.032 & $0.097 * * *$ & 0.023 & 0.002 \\
\hline (3) ROAD DISTANCE & $0.126^{* * *}$ & $0.994 * * *$ & & $0.858 * * *$ & -0.033 & $0.073^{* *}$ & -0.009 & -0.024 & -0.033 & 0.039 & $0.097 * * *$ & 0.024 & 0.003 \\
\hline (4) OUTSIDE_PARIS & $0.106 * * *$ & $0.905^{* * *}$ & $0.889 * * *$ & & 0.004 & $0.110^{* * *}$ & -0.000 & -0.027 & 0.020 & 0.018 & $0.107 * * *$ & 0.010 & 0.005 \\
\hline (5) SIZE & $0.367 * * *$ & -0.023 & -0.03 & -0.001 & & $0.367 * * *$ & $0.134 * * *$ & 0.019 & $0.217 * * *$ & $0.132 * * *$ & $-0.151^{* * *}$ & -0.045 & $0.078 * *$ \\
\hline (6) LEVERAGE & 0.042 & 0.034 & 0.059 & $0.082 * * *$ & $0.314^{* * *}$ & & $-0.145^{* * *}$ & $0.126^{* * *}$ & 0.038 & 0.042 & $-0.385 * * *$ & -0.031 & $0.264^{* * *}$ \\
\hline (7) $R O A$ & 0.041 & 0.002 & 0.005 & 0.021 & $0.259 * * *$ & -0.011 & & -0.018 & 0.014 & 0.017 & $0.164 * * *$ & $0.367 * * *$ & $-0.132 * * *$ \\
\hline (8) BIG4 & $0.116^{* * *}$ & -0.034 & -0.034 & -0.027 & 0.015 & -0.023 & -0.011 & & $-0.122 * * *$ & -0.036 & $-0.159 * * *$ & -0.015 & 0.042 \\
\hline (9) ANALYST & $0.169 * * *$ & 0.001 & -0.007 & 0.034 & $0.233^{* * *}$ & -0.016 & -0.023 & $-0.132 * * *$ & & $0.194^{* * *}$ & $-0.060 *$ & $0.063^{* *}$ & $0.125^{* * *}$ \\
\hline (10) XLIST & $0.160 * * *$ & 0.052 & $0.056 *$ & 0.018 & $0.103^{* * *}$ & -0.006 & 0.021 & -0.036 & $0.258 * * *$ & & -0.004 & $0.062 * *$ & $0.091 * * *$ \\
\hline (11) LIQUIDITY & -0.031 & 0.052 & $0.103^{* * *}$ & $0.096 * * *$ & $-0.139 * * *$ & -0.044 & 0.033 & $-0.168^{* * *}$ & $-0.054 *$ & -0.014 & & $0.153^{* * *}$ & $-0.154 * * *$ \\
\hline (12) $M B$ & -0.022 & -0.001 & -0.021 & -0.021 & $-0.136 * * *$ & $0.198 * * *$ & $0.106^{* * *}$ & -0.039 & $0.076 * *$ & 0.027 & $0.087 * * *$ & & 0.021 \\
\hline (13) ISSUE & $0.173^{* * *}$ & 0.006 & 0.003 & 0.005 & $0.097 * * *$ & 0.008 & $-0.067 * *$ & 0.042 & $0.152^{* * *}$ & $0.092^{* * *}$ & $-0.118^{* * *}$ & 0.021 & \\
\hline
\end{tabular}

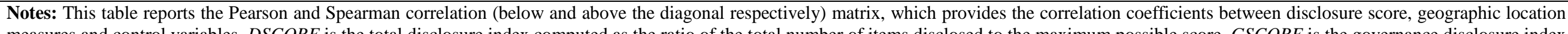

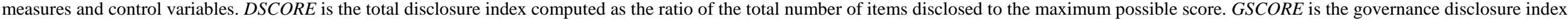

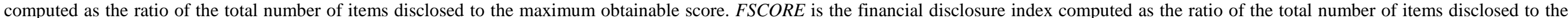

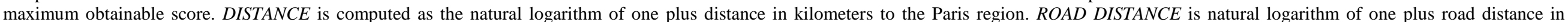

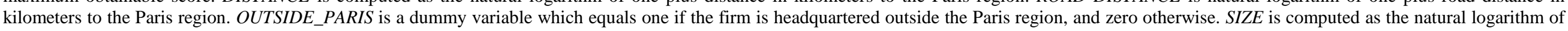

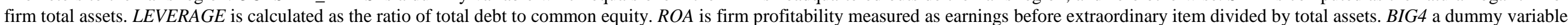

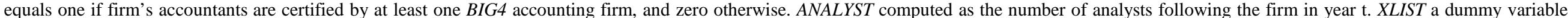

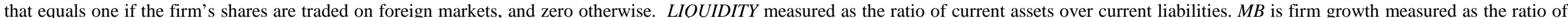

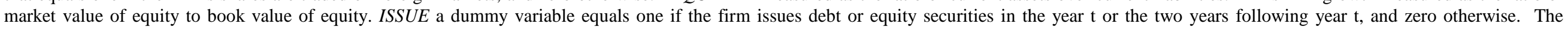
superscripts asterisks *,**, and *** denote statistical significance at the $0.10,0.05$, and 0.01 levels, respectively. 
Table 3. Geography and voluntary disclosure: Univariate evidence

\begin{tabular}{|c|c|c|c|c|}
\hline Geographic location measures & & Below Median & Above Median & $P$-value of difference \\
\hline \multicolumn{5}{|c|}{ Panel A: Voluntary disclosure based on geographic location measures } \\
\hline DISTANCE_D & Mean & 0.3812 & 0.4088 & $(0.00)^{* * *}$ \\
\hline ROAD DISTANCE_D & Mean & 0.3825 & 0.4069 & $(0.00)^{* * *}$ \\
\hline OUTSIDE_PARIS & Mean & 0.3815 & 0.4085 & $(0.00)^{* * *}$ \\
\hline Firm characteristics & & Below Median & Above Median & $P$-value of difference \\
\hline \multicolumn{5}{|c|}{ Panel B: Voluntary disclosure based on firm characteristics } \\
\hline SIZE & Mean & 0.3585 & 0.4306 & $(0.00)^{* * *}$ \\
\hline LEVERAGE & Mean & 0.3804 & 0.4088 & $(0.00)^{* * *}$ \\
\hline$R O A$ & Mean & 0.3899 & 0.3993 & $(0.23)$ \\
\hline Big4 & Mean & 0.3815 & 0.4111 & $(0.00)^{* * *}$ \\
\hline ANALYST & Mean & 0.3919 & 0.3976 & $(0.47)$ \\
\hline XLIST & Mean & 0.3916 & 0.5335 & $(0.00)^{* * *}$ \\
\hline LIQUIDITY & Mean & 0.4007 & 0.3946 & $(0.12)$ \\
\hline$M B$ & Mean & 0.3824 & 0.4068 & $(0.00)^{* * *}$ \\
\hline ISSUE & Mean & 0.3866 & 0.4549 & $(0.00)^{* * *}$ \\
\hline \multicolumn{5}{|c|}{ 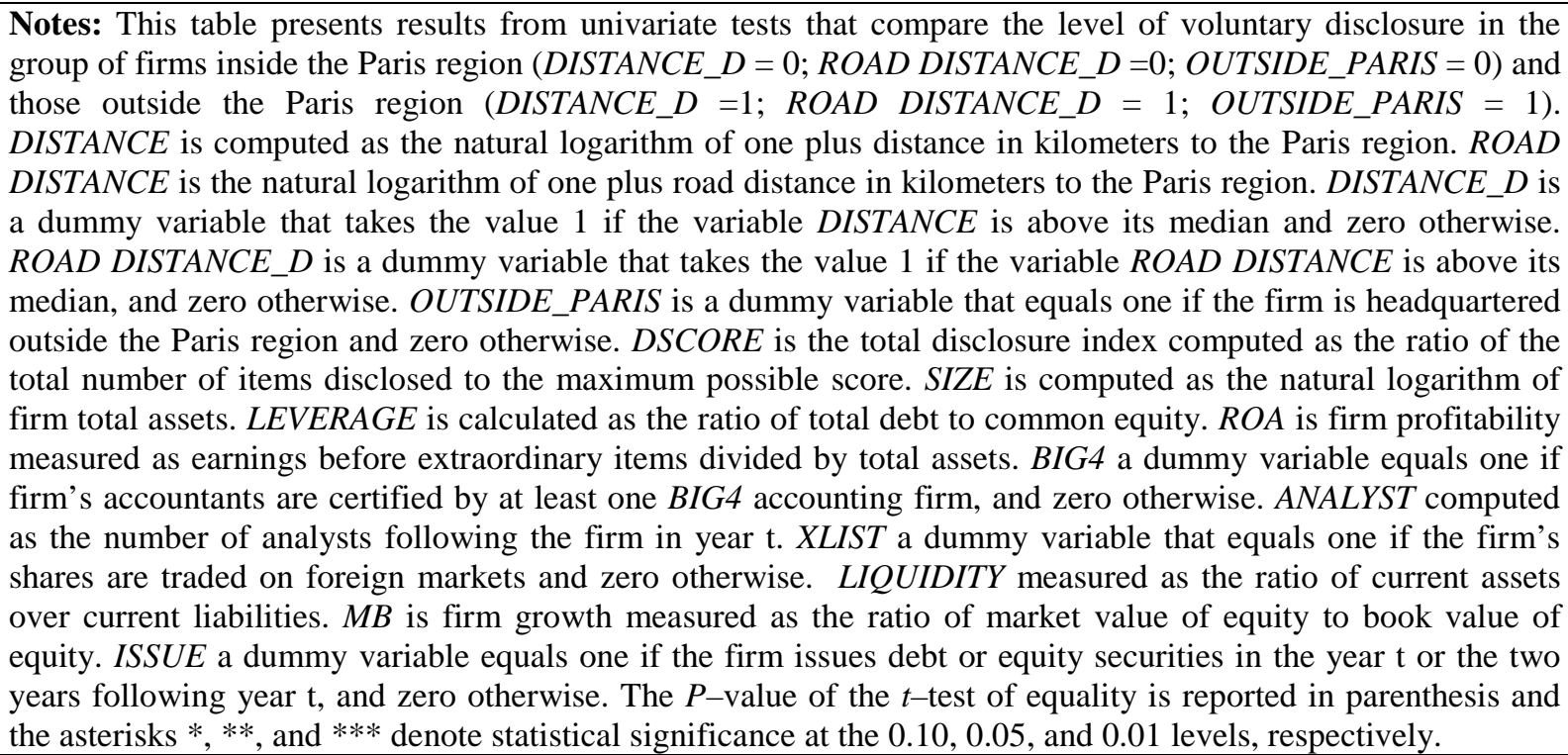 } \\
\hline
\end{tabular}


Table 4. Geography and voluntary disclosure: multivariate analysis

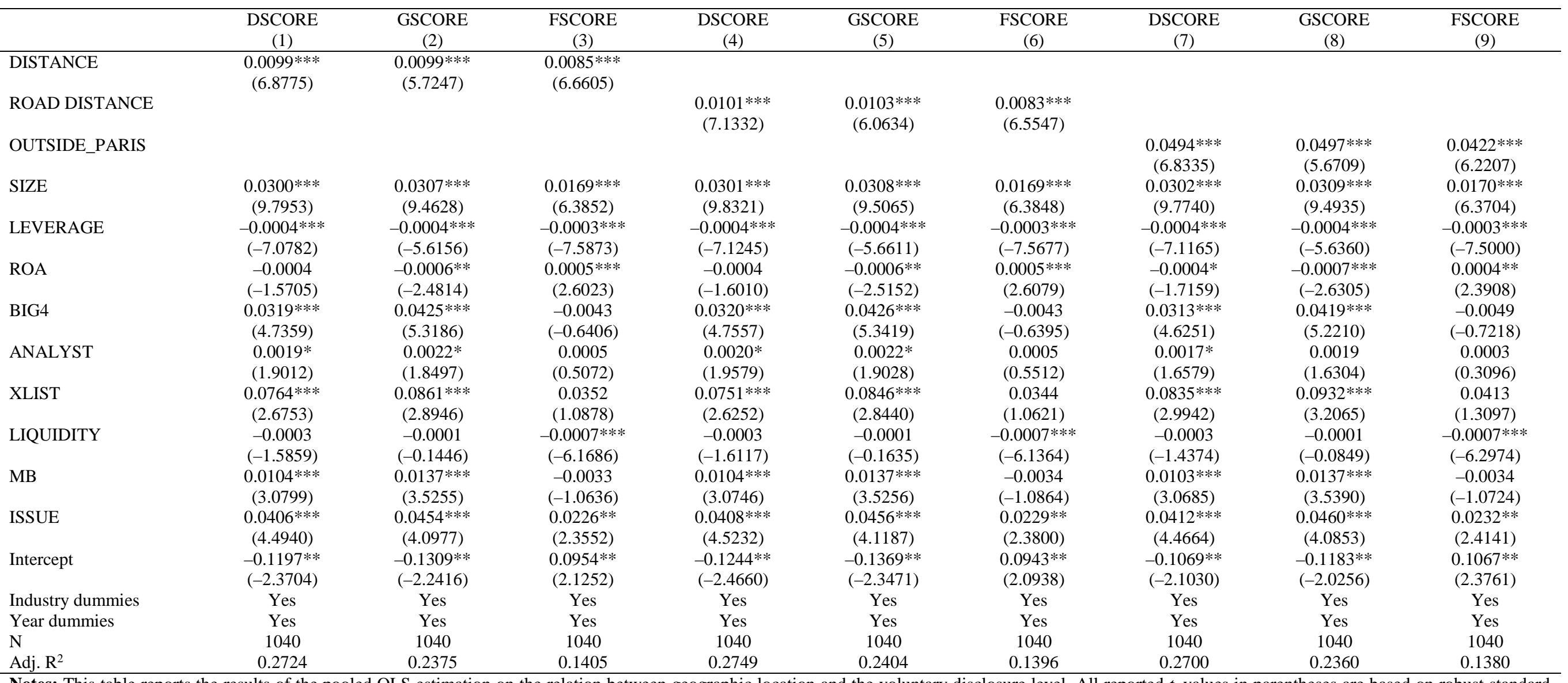

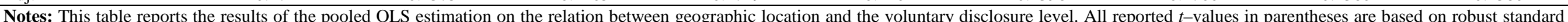

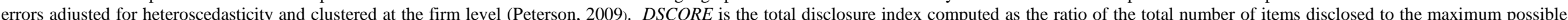

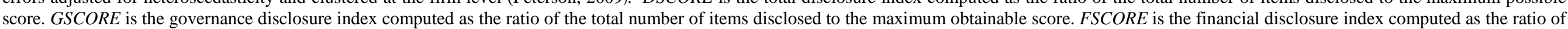

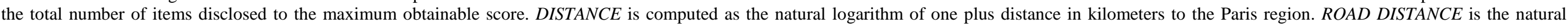

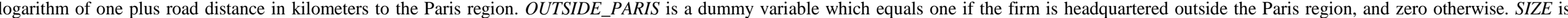

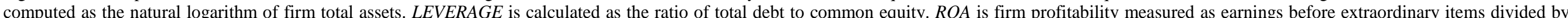

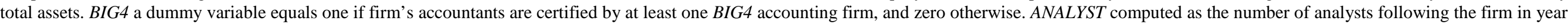

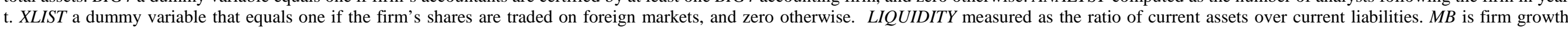

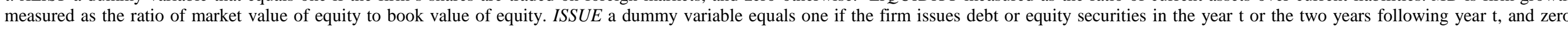

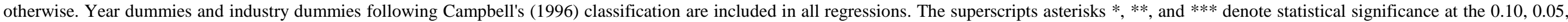
and 0.01 levels, respectively. 
Table 5. Alternative measure of the dependent variable: the natural logarithm of the disclosure score

\begin{tabular}{|c|c|c|c|c|c|c|c|c|c|}
\hline & $\begin{array}{c}\text { LNDSCORE } \\
(1) \\
\end{array}$ & $\begin{array}{c}\text { LNGOV } \\
(2)\end{array}$ & $\begin{array}{c}\text { LNFIN } \\
(3)\end{array}$ & $\begin{array}{c}\text { LNDSCORE } \\
(4) \\
\end{array}$ & $\begin{array}{c}\text { LNGOV } \\
(5)\end{array}$ & $\begin{array}{l}\text { LNFIN } \\
(6)\end{array}$ & $\begin{array}{c}\text { LNDSCORE } \\
(7)\end{array}$ & $\begin{array}{l}\text { LNGOV } \\
\text { (8) }\end{array}$ & $\begin{array}{l}\text { LNFIN } \\
(9)\end{array}$ \\
\hline DISTANCE & $\begin{array}{c}0.0298 * * * \\
(6.6370)\end{array}$ & $\begin{array}{c}0.0297 * * * \\
(5.6555)\end{array}$ & $\begin{array}{c}0.0262^{* * * *} \\
(6.0129)\end{array}$ & & & & & & \\
\hline ROAD DISTANCE & & & & $\begin{array}{c}0.0304 * * * \\
(6.8449)\end{array}$ & $\begin{array}{c}0.0306 * * * \\
(5.9137)\end{array}$ & $\begin{array}{c}0.0255^{* * *} \\
(5.9083)\end{array}$ & & & \\
\hline OUTSIDE_PARIS & & & & & & & $\begin{array}{c}0.1461 * * * \\
(6.6344)\end{array}$ & $\begin{array}{c}0.1489 * * * \\
(5.7354)\end{array}$ & $\begin{array}{c}0.1335 * * * \\
(5.8062)\end{array}$ \\
\hline SIZE & $\begin{array}{c}0.0899 * * * \\
(9.9281)\end{array}$ & $\begin{array}{c}0.0819 * * * \\
(8.7381)\end{array}$ & $\begin{array}{c}0.0714 * * * \\
(7.8489)\end{array}$ & $\begin{array}{c}0.0901 * * * \\
(9.9685)\end{array}$ & $\begin{array}{c}0.0822 * * * \\
(8.7773)\end{array}$ & $\begin{array}{c}0.0714 * * * \\
(7.8485)\end{array}$ & $\begin{array}{c}0.0904 * * * \\
(9.8730)\end{array}$ & $\begin{array}{c}0.0825 * * * \\
(8.7722)\end{array}$ & $\begin{array}{c}0.0720 * * * \\
(7.8149)\end{array}$ \\
\hline LEVERAGE & $\begin{array}{c}-0.0011 * * * \\
(-7.9692)\end{array}$ & $\begin{array}{c}-0.0010 * * * \\
(-6.2236)\end{array}$ & $\begin{array}{c}-0.0014 * * * \\
(-8.8627)\end{array}$ & $\begin{array}{c}-0.0011^{* * *} \\
(-8.0068)\end{array}$ & $\begin{array}{c}-0.0010 * * * \\
(-6.2674)\end{array}$ & $\begin{array}{c}-0.0014 * * * \\
(-8.8559)\end{array}$ & $\begin{array}{c}-0.0011^{* * *} \\
(-7.8481)\end{array}$ & $\begin{array}{c}-0.0009 * * * \\
(-6.1787)\end{array}$ & $\begin{array}{c}-0.0013 * * * \\
(-8.8732)\end{array}$ \\
\hline ROA & $\begin{array}{l}-0.0006 \\
(-0.5813)\end{array}$ & $\begin{array}{l}-0.0014 \\
(-1.4536)\end{array}$ & $\begin{array}{c}0.0022 * * * \\
(2.9939)\end{array}$ & $\begin{array}{l}-0.0006 \\
(-0.5997)\end{array}$ & $\begin{array}{l}-0.0014 \\
(-1.4771)\end{array}$ & $\begin{array}{c}0.0022 * * * \\
(3.0033)\end{array}$ & $\begin{array}{l}-0.0007 \\
(-0.6993)\end{array}$ & $\begin{array}{l}-0.0015 \\
(-1.5982)\end{array}$ & $\begin{array}{c}0.0021 * * * \\
(2.8094)\end{array}$ \\
\hline BIG4 & $\begin{array}{c}0.0887 * * * \\
(4.2366)\end{array}$ & $\begin{array}{c}0.1136 * * * \\
(4.7568)\end{array}$ & $\begin{array}{l}-0.0049 \\
(-0.2104)\end{array}$ & $\begin{array}{c}0.0890 * * * \\
(4.2560)\end{array}$ & $\begin{array}{c}0.1138 * * * \\
(4.7788)\end{array}$ & $\begin{array}{l}-0.0049 \\
(-0.2092)\end{array}$ & $\begin{array}{c}0.0868 * * * \\
(4.1234)\end{array}$ & $\begin{array}{c}0.1117 * * * \\
(4.6547)\end{array}$ & $\begin{array}{l}-0.0065 \\
(-0.2801)\end{array}$ \\
\hline ANALYST & $\begin{array}{c}0.0029 \\
(0.9824)\end{array}$ & $\begin{array}{c}0.0036 \\
(1.1197)\end{array}$ & $\begin{array}{c}0.0016 \\
(0.4948)\end{array}$ & $\begin{array}{c}0.0031 \\
(1.0384)\end{array}$ & $\begin{array}{c}0.0038 \\
(1.1733)\end{array}$ & $\begin{array}{c}0.0018 \\
(0.5350)\end{array}$ & $\begin{array}{c}0.0022 \\
(0.7450)\end{array}$ & $\begin{array}{c}0.0029 \\
(0.8939)\end{array}$ & $\begin{array}{c}0.0010 \\
(0.3082)\end{array}$ \\
\hline XLIST & $\begin{array}{c}0.1929 * * * \\
(2.6419)\end{array}$ & $\begin{array}{c}0.2084 * * * \\
(2.9707)\end{array}$ & $\begin{array}{c}0.0887 \\
(0.8565)\end{array}$ & $\begin{array}{c}0.1889 * * * \\
(2.5839)\end{array}$ & $\begin{array}{c}0.2040 * * * \\
(2.9082)\end{array}$ & $\begin{array}{c}0.0863 \\
(0.8321)\end{array}$ & $\begin{array}{c}0.2141 * * * \\
(3.0019)\end{array}$ & $\begin{array}{c}0.2294 * * * \\
(3.3520)\end{array}$ & $\begin{array}{c}0.1072 \\
(1.0644)\end{array}$ \\
\hline LIQUIDITY & $\begin{array}{l}-0.0012^{*} \\
(-1.8669)\end{array}$ & $\begin{array}{l}-0.0002 \\
(-0.2258)\end{array}$ & $\begin{array}{c}-0.0023 * * * \\
(-6.4763)\end{array}$ & $\begin{array}{l}-0.0012^{*} \\
(-1.8935)\end{array}$ & $\begin{array}{l}-0.0002 \\
(-0.2465)\end{array}$ & $\begin{array}{c}-0.0023^{* * *} \\
(-6.4710)\end{array}$ & $\begin{array}{l}-0.0011^{*} \\
(-1.7035)\end{array}$ & $\begin{array}{l}-0.0001 \\
(-0.1547)\end{array}$ & $\begin{array}{c}-0.0022 * * * \\
(-6.4647)\end{array}$ \\
\hline MB & $\begin{array}{c}0.0218 * * \\
(1.9960)\end{array}$ & $\begin{array}{c}0.0310 * * * \\
(2.5988)\end{array}$ & $\begin{array}{l}-0.0141 \\
(-1.2786)\end{array}$ & $\begin{array}{c}0.0217 * * \\
(1.9890)\end{array}$ & $\begin{array}{c}0.0310 * * * \\
(2.5958)\end{array}$ & $\begin{array}{l}-0.0143 \\
(-1.2980)\end{array}$ & $\begin{array}{c}0.0215 * * \\
(1.9845)\end{array}$ & $\begin{array}{c}0.0309 * * * \\
(2.6127)\end{array}$ & $\begin{array}{l}-0.0142 \\
(-1.2790)\end{array}$ \\
\hline ISSUE & $\begin{array}{c}0.1220 * * * \\
(4.7118)\end{array}$ & $\begin{array}{c}0.1329 * * * \\
(4.6433)\end{array}$ & $\begin{array}{c}0.0906 * * * \\
(2.8756)\end{array}$ & $\begin{array}{c}0.1226^{* * *} \\
(4.7407)\end{array}$ & $\begin{array}{c}0.1335^{* * *} \\
(4.6658)\end{array}$ & $\begin{array}{c}0.0913 * * * \\
(2.8998)\end{array}$ & $\begin{array}{c}0.1239 * * * \\
(4.6709)\end{array}$ & $\begin{array}{c}0.1347 * * * \\
(4.6087)\end{array}$ & $\begin{array}{c}0.0922 * * * \\
(2.9064)\end{array}$ \\
\hline Intercept & $\begin{array}{c}-2.5019 * * * \\
(-17.2372)\end{array}$ & $\begin{array}{c}-2.4050 * * * \\
(-15.1977)\end{array}$ & $\begin{array}{c}-2.1923 * * * \\
(-15.2195)\end{array}$ & $\begin{array}{c}-2.5163 * * * \\
(-17.3611)\end{array}$ & $\begin{array}{c}-2.4220 * * * \\
(-15.3204)\end{array}$ & $\begin{array}{c}-2.1962 * * * \\
(-15.2103)\end{array}$ & $\begin{array}{c}-2.4611^{* * *} \\
(-16.7863)\end{array}$ & $\begin{array}{c}-2.3683 * * * \\
(-14.9142)\end{array}$ & $\begin{array}{c}-2.1621^{* * *} \\
(-14.9707)\end{array}$ \\
\hline Industry dummies & Yes & Yes & Yes & Yes & Yes & Yes & Yes & Yes & Yes \\
\hline Year dummies & Yes & Yes & Yes & Yes & Yes & Yes & Yes & Yes & Yes \\
\hline $\mathrm{N}$ & 1040 & 1040 & 1040 & 1040 & 1040 & 1040 & 1040 & 1040 & 1040 \\
\hline Adj. $R^{2}$ & 0.2469 & 0.1982 & 0.1701 & 0.2495 & 0.2010 & 0.1695 & 0.2436 & 0.1968 & 0.1696 \\
\hline
\end{tabular}

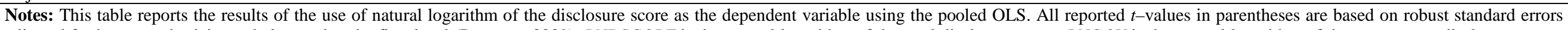

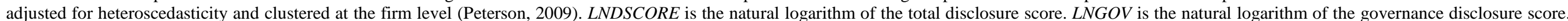

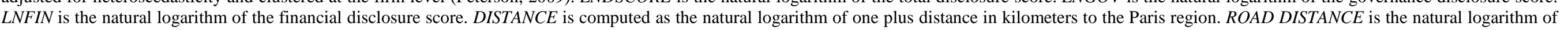

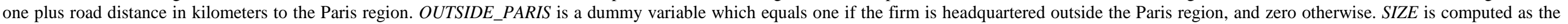

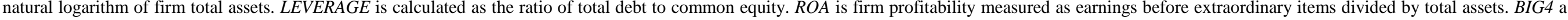

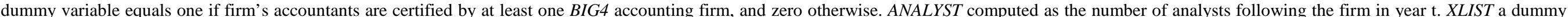

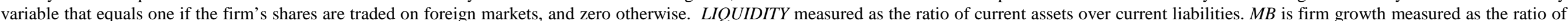

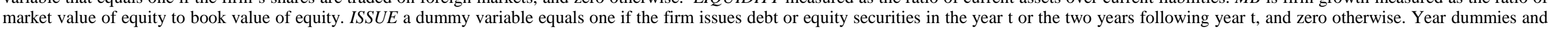

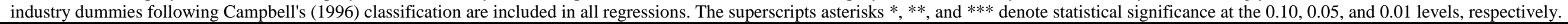


Table 6. Alternative measure of the dependent variable: Industry-adjusted score

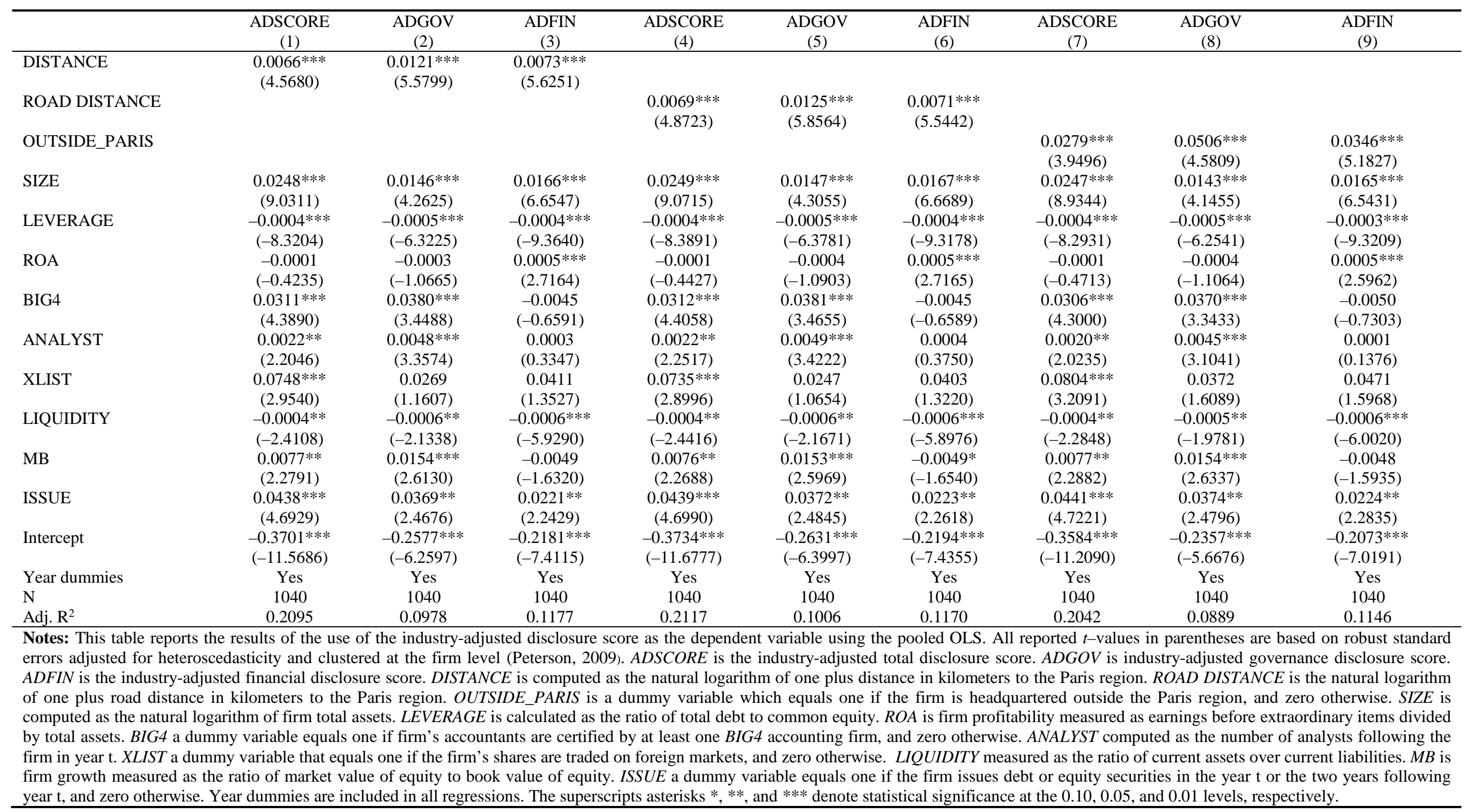


Table 7. Alternative geographic location proxies

\begin{tabular}{|c|c|c|c|c|c|c|}
\hline & $\begin{array}{c}\text { DSCORE } \\
\text { (1) }\end{array}$ & $\begin{array}{c}\text { GSCORE } \\
(2)\end{array}$ & $\begin{array}{c}\text { FSCORE } \\
(3) \\
\end{array}$ & $\begin{array}{c}\text { DSCORE } \\
(4)\end{array}$ & $\begin{array}{c}\text { GSCORE } \\
\text { (5) }\end{array}$ & $\begin{array}{c}\text { FSCORE } \\
(6) \\
\end{array}$ \\
\hline DISTANCE100 & $\begin{array}{c}0.0479 * * * \\
(6.6106)\end{array}$ & $\begin{array}{c}0.0489 * * * \\
(5.6190)\end{array}$ & $\begin{array}{c}0.0392 * * * \\
(5.6910)\end{array}$ & & & \\
\hline DISTANCE250 & & & & $\begin{array}{c}0.0429 * * * \\
(5.9764)\end{array}$ & $\begin{array}{c}0.0425 * * * \\
(4.9552)\end{array}$ & $\begin{array}{c}0.0375 * * * \\
(5.4642)\end{array}$ \\
\hline SIZE & $\begin{array}{c}0.0295^{* * *} \\
(9.6866)\end{array}$ & $\begin{array}{c}0.0303^{* * * *} \\
(9.3784)\end{array}$ & $\begin{array}{c}0.0164^{* * * *} \\
(6.2415)\end{array}$ & $\begin{array}{c}0.0290 * * * \\
(9.4952)\end{array}$ & $\begin{array}{c}0.0297 * * * \\
(9.1946)\end{array}$ & $\begin{array}{c}0.0160^{* * * *} \\
(6.0430)\end{array}$ \\
\hline LEVERAGE & $\begin{array}{c}-0.0004 * * * \\
(-7.0794)\end{array}$ & $\begin{array}{c}-0.0004 * * * \\
(-5.6125)\end{array}$ & $\begin{array}{c}-0.0003 * * * \\
(-7.4554)\end{array}$ & $\begin{array}{c}-0.0004 * * * \\
(-7.3400)\end{array}$ & $\begin{array}{c}-0.0004 * * * \\
(-5.8384)\end{array}$ & $\begin{array}{c}-0.0003 * * * \\
(-7.4234)\end{array}$ \\
\hline ROA & $\begin{array}{c}-0.0004 \\
(-1.5258)\end{array}$ & $\begin{array}{c}-0.0006^{* *} \\
(-2.4630)\end{array}$ & $\begin{array}{c}0.0005^{* * *} \\
(2.5835)\end{array}$ & $\begin{array}{c}-0.0003 \\
(-1.3575)\end{array}$ & $\begin{array}{c}-0.0006^{* *} \\
(-2.2940)\end{array}$ & $\begin{array}{c}0.0005^{* * *} \\
(2.6900)\end{array}$ \\
\hline BIG4 & $\begin{array}{c}0.0310 * * * \\
(4.5667)\end{array}$ & $\begin{array}{c}0.0415^{* * *} \\
(5.1788)\end{array}$ & $\begin{array}{c}-0.0052 \\
(-0.7632)\end{array}$ & $\begin{array}{c}0.0336 * * * \\
(4.9352)\end{array}$ & $\begin{array}{c}0.0441 * * * \\
(5.4683)\end{array}$ & $\begin{array}{c}-0.0028 \\
(-0.4190)\end{array}$ \\
\hline ANALYST & $\begin{array}{c}0.0017^{*} \\
(1.6723)\end{array}$ & $\begin{array}{c}0.0019 \\
(1.6378)\end{array}$ & $\begin{array}{c}0.0003 \\
(0.3250)\end{array}$ & $\begin{array}{c}0.0019 * \\
(1.8399)\end{array}$ & $\begin{array}{l}0.0021^{*} \\
(1.7901)\end{array}$ & $\begin{array}{c}0.0004 \\
(0.4589)\end{array}$ \\
\hline XLIST & $\begin{array}{c}0.0832 * * * \\
(3.0227)\end{array}$ & $\begin{array}{c}0.0929 * * * \\
(3.2303)\end{array}$ & $\begin{array}{c}0.0411 \\
(1.3134)\end{array}$ & $\begin{array}{c}0.0815 * * * \\
(2.9733)\end{array}$ & $\begin{array}{c}0.0912 * * * \\
(3.1746)\end{array}$ & $\begin{array}{c}0.0395 \\
(1.2669)\end{array}$ \\
\hline LIQUIDITY & $\begin{array}{c}-0.0003 \\
(-1.4628)\end{array}$ & $\begin{array}{c}-0.0001 \\
(-0.0869)\end{array}$ & $\begin{array}{c}-0.0007^{* * * *} \\
(-6.1652)\end{array}$ & $\begin{array}{c}-0.0003 \\
(-1.5226)\end{array}$ & $\begin{array}{c}-0.0001 \\
(-0.1018)\end{array}$ & $\begin{array}{c}-0.0007^{* * *} * \\
(-6.1084)\end{array}$ \\
\hline MB & $\begin{array}{c}0.0099 * * * \\
(2.9542)\end{array}$ & $\begin{array}{c}0.0132 * * * \\
(3.4378)\end{array}$ & $\begin{array}{c}-0.0038 \\
(-1.2063)\end{array}$ & $\begin{array}{c}0.0100 * * * \\
(2.9843)\end{array}$ & $\begin{array}{c}0.0133 * * * \\
(3.4586)\end{array}$ & $\begin{array}{c}-0.0037 \\
(-1.1701)\end{array}$ \\
\hline ISSUE & $\begin{array}{c}0.0405^{* * *} \\
(4.4062)\end{array}$ & $\begin{array}{c}0.0453^{* * *} \\
(4.0306)\end{array}$ & $\begin{array}{c}0.0227 * * \\
(2.3660)\end{array}$ & $\begin{array}{c}0.0402^{* * *} \\
(4.3187)\end{array}$ & $\begin{array}{c}0.0450 * * * \\
(3.9631)\end{array}$ & $\begin{array}{c}0.0222 * * \\
(2.3113)\end{array}$ \\
\hline Intercept & $\begin{array}{l}-0.0955^{*} \\
(-1.9088)\end{array}$ & $\begin{array}{l}-0.1076^{*} \\
(-1.8614)\end{array}$ & $\begin{array}{c}0.1180 * * * \\
(2.6574)\end{array}$ & $\begin{array}{l}-0.0861^{*} \\
(-1.7195)\end{array}$ & $\begin{array}{l}-0.0969 * \\
(-1.6790)\end{array}$ & $\begin{array}{c}0.1238 * * * \\
(2.7702)\end{array}$ \\
\hline Industry dummies & Yes & Yes & Yes & Yes & Yes & Yes \\
\hline Year dummies & Yes & Yes & Yes & Yes & Yes & Yes \\
\hline $\mathrm{N}$ & 1040 & 1040 & 1040 & 1040 & 1040 & 1040 \\
\hline Adj. $R^{2}$ & 0.2682 & 0.2354 & 0.1339 & 0.2620 & 0.2294 & 0.1318 \\
\hline
\end{tabular}

Notes: This table reports the results of the use of alternative measures of the geographic location using the pooled OLS. All reported $t$-values in parentheses are based on robust standard errors adjusted for heteroscedasticity and clustered at the firm level (Peterson, 2009). DISTANCE100 is a dummy variable that equals one if the firm is located more than 100 kilometers to the Paris region, and zero otherwise. DISTANCE 250 is a dummy variable that equals one if the firm is located more than 250 kilometers to the Paris region, and zero otherwise. SIZE is computed as the natural logarithm of firm total assets. LEVERAGE is calculated as the ratio of total debt to common equity. ROA is firm profitability measured as earnings before extraordinary items divided by total assets. BIG4 a dummy variable equals one if firm's accountants are certified by at least one BIG4 accounting firm, and zero otherwise. ANALYST computed as the number of analysts following the firm in year t. XLIST a dummy variable that equals one if the firm's shares are traded on foreign markets, and zero otherwise. LIQUIDITY measured as the ratio of current assets over current liabilities. $M B$ is firm growth measured as the ratio of market value of equity to book value of equity. ISSUE a dummy variable equals one if the firm issues debt or equity securities in the year $t$ or the two years following year t, and zero otherwise. Year dummies and industry dummies following Campbell's (1996) classification are included in all regressions. The superscripts asterisks *, **, and *** denote statistical significance at the $0.10,0.05$, and 0.01 levels, respectively. 
Table 8. Alternative statistical approaches

\begin{tabular}{|c|c|c|c|c|c|c|c|c|c|}
\hline & \multicolumn{3}{|c|}{ Fama MacBeth } & \multicolumn{3}{|c|}{ Fama MacBeth with Newey-West standard errors } & \multicolumn{3}{|c|}{ Firm random effects } \\
\hline & $\begin{array}{l}\text { DSCORE } \\
\text { (1) }\end{array}$ & $\begin{array}{c}\text { GSCORE } \\
\text { (2) }\end{array}$ & $\begin{array}{c}\text { FSCORE } \\
\text { (3) }\end{array}$ & $\begin{array}{c}\text { DSCORE } \\
\text { (4) }\end{array}$ & $\begin{array}{c}\text { GSCORE } \\
\text { (5) }\end{array}$ & $\begin{array}{c}\text { FSCORE } \\
(6)\end{array}$ & $\begin{array}{c}\text { DSCORE } \\
(7)\end{array}$ & $\begin{array}{c}\text { GSCORE } \\
\text { (8) }\end{array}$ & $\begin{array}{c}\text { FSCORE } \\
(9)\end{array}$ \\
\hline DISTANCE & $\begin{array}{c}0.0099 * * * \\
(22.9646)\end{array}$ & $\begin{array}{c}0.0098 * * * \\
(22.3251)\end{array}$ & $\begin{array}{c}0.0087 * * * \\
(28.4099)\end{array}$ & $\begin{array}{c}0.0099 * * * \\
(22.3431)\end{array}$ & $\begin{array}{c}0.0098 * * * \\
(23.1446)\end{array}$ & $\begin{array}{c}0.0087 * * * \\
(30.7125)\end{array}$ & $\begin{array}{c}0.0099 * * * \\
(7.0455)\end{array}$ & $\begin{array}{c}0.0099 * * * \\
(5.8752)\end{array}$ & $\begin{array}{c}0.0085 * * * \\
(6.3197)\end{array}$ \\
\hline SIZE & $\begin{array}{c}0.0301^{* * *} \\
(12.8048)\end{array}$ & $\begin{array}{c}0.0309 * * * \\
(9.8060)\end{array}$ & $\begin{array}{c}0.0171^{* * *} \\
(15.4868)\end{array}$ & $\begin{array}{c}0.0301 * * * \\
(12.0316)\end{array}$ & $\begin{array}{c}0.0309 * * * \\
(9.3986)\end{array}$ & $\begin{array}{c}0.0171 * * * \\
(19.9314)\end{array}$ & $\begin{array}{c}0.0300 * * * \\
(12.8525)\end{array}$ & $\begin{array}{c}0.0307 * * * \\
(11.0075)\end{array}$ & $\begin{array}{c}0.0169 * * * \\
(7.5372)\end{array}$ \\
\hline LEVERAGE & $\begin{array}{c}-0.0014 * * \\
(-3.4209)\end{array}$ & $\begin{array}{l}-0.0015^{*} \\
(-3.1215)\end{array}$ & $\begin{array}{c}-0.0010 \\
(-1.1652)\end{array}$ & $\begin{array}{c}-0.0014 * * \\
(-4.5881)\end{array}$ & $\begin{array}{c}-0.0015 * * \\
(-5.5078)\end{array}$ & $\begin{array}{c}-0.0010 \\
(-1.2291)\end{array}$ & $\begin{array}{c}-0.0004 * * \\
(-2.1622)\end{array}$ & $\begin{array}{l}-0.0004^{*} \\
(-1.8375)\end{array}$ & $\begin{array}{l}-0.0004^{*} \\
(-1.9406)\end{array}$ \\
\hline ROA & $\begin{array}{c}-0.0003 \\
(-1.7244)\end{array}$ & $\begin{array}{l}-0.0006^{*} \\
(-2.7124)\end{array}$ & $\begin{array}{l}0.0005^{*} \\
(2.7201)\end{array}$ & $\begin{array}{l}-0.0003^{*} \\
(-2.9193)\end{array}$ & $\begin{array}{c}-0.0006 * * \\
(-3.6088)\end{array}$ & $\begin{array}{c}0.0005^{* *} \\
(4.4261)\end{array}$ & $\begin{array}{l}-0.0004^{*} \\
(-1.7838)\end{array}$ & $\begin{array}{c}-0.0007 * * \\
(-2.5429)\end{array}$ & $\begin{array}{c}0.0005^{* *} \\
(2.1411)\end{array}$ \\
\hline BIG4 & $\begin{array}{c}0.0332 * * * \\
(16.0736)\end{array}$ & $\begin{array}{c}0.0442 * * * \\
(20.7493)\end{array}$ & $\begin{array}{c}-0.0046 \\
(-1.6720)\end{array}$ & $\begin{array}{c}0.0332 * * * \\
(16.6631)\end{array}$ & $\begin{array}{c}0.0442 * * * \\
(30.3875)\end{array}$ & $\begin{array}{c}-0.0046 \\
(-1.7719)\end{array}$ & $\begin{array}{c}0.0315 * * * \\
(4.5081)\end{array}$ & $\begin{array}{c}0.0417 * * * \\
(4.9917)\end{array}$ & $\begin{array}{c}-0.0043 \\
(-0.6473)\end{array}$ \\
\hline ANALYST & $\begin{array}{c}0.0020^{* *} \\
(3.4742)\end{array}$ & $\begin{array}{l}0.0023 * * \\
(3.8451)\end{array}$ & $\begin{array}{c}0.0004 \\
(0.5662)\end{array}$ & $\begin{array}{c}0.0020 * * \\
(3.3779)\end{array}$ & $\begin{array}{c}0.0023 * * \\
(3.9243)\end{array}$ & $\begin{array}{c}0.0004 \\
(0.5383)\end{array}$ & $\begin{array}{c}0.0017 * \\
(1.9060)\end{array}$ & $\begin{array}{c}0.0018 * \\
(1.6737)\end{array}$ & $\begin{array}{c}0.0005 \\
(0.5532)\end{array}$ \\
\hline XLIST & $\begin{array}{c}0.0615 * \\
(3.0462)\end{array}$ & $\begin{array}{c}0.0766^{* *} \\
(4.4377)\end{array}$ & $\begin{array}{c}-0.0039 \\
(-0.0665)\end{array}$ & $\begin{array}{c}0.0615^{* *} \\
(4.0022)\end{array}$ & $\begin{array}{c}0.0766 * * * \\
(8.1933)\end{array}$ & $\begin{array}{c}-0.0039 \\
(-0.0678)\end{array}$ & $\begin{array}{c}0.0847 * * * \\
(3.3686)\end{array}$ & $\begin{array}{c}0.0990 * * * \\
(3.2907)\end{array}$ & $\begin{array}{c}0.0349 \\
(1.4431)\end{array}$ \\
\hline LIQUIDITY & $\begin{array}{c}0.0023 \\
(0.7560)\end{array}$ & $\begin{array}{c}0.0038 \\
(0.9065)\end{array}$ & $\begin{array}{c}-0.0013^{* *} \\
(-3.3001)\end{array}$ & $\begin{array}{c}0.0023 \\
(0.8953)\end{array}$ & $\begin{array}{c}0.0038 \\
(1.0488)\end{array}$ & $\begin{array}{l}-0.0013^{*} \\
(-3.1786)\end{array}$ & $\begin{array}{c}-0.0004 \\
(-1.2411)\end{array}$ & $\begin{array}{c}-0.0002 \\
(-0.4042)\end{array}$ & $\begin{array}{c}-0.0007^{* *} \\
(-2.2112)\end{array}$ \\
\hline MB & $\begin{array}{c}0.0102 * * * \\
(5.8992)\end{array}$ & $\begin{array}{c}0.0135 * * * \\
(8.7453)\end{array}$ & $\begin{array}{c}-0.0033 \\
(-1.3835)\end{array}$ & $\begin{array}{c}0.0102 * * * \\
(6.8067)\end{array}$ & $\begin{array}{c}0.0135^{* * *} \\
(11.3018)\end{array}$ & $\begin{array}{c}-0.0033 \\
(-1.3948)\end{array}$ & $\begin{array}{c}0.0079 * * \\
(2.5537)\end{array}$ & $\begin{array}{c}0.0099 * * * \\
(2.6867)\end{array}$ & $\begin{array}{c}-0.0031 \\
(-1.0415)\end{array}$ \\
\hline ISSUE & $\begin{array}{c}0.0419 * * * \\
(18.6795)\end{array}$ & $\begin{array}{c}0.0471^{* * * *} \\
(7.4144)\end{array}$ & $\begin{array}{c}0.0224 \\
(2.3366)\end{array}$ & $\begin{array}{c}0.0419 * * * \\
(36.7225)\end{array}$ & $\begin{array}{c}0.0471 * * * \\
(7.8971)\end{array}$ & $\begin{array}{c}0.0224 * \\
(2.4049)\end{array}$ & $\begin{array}{c}0.0414 * * * \\
(3.7785)\end{array}$ & $\begin{array}{c}0.0471^{* * * *} \\
(3.5917)\end{array}$ & $\begin{array}{c}0.0226 * * \\
(2.1480)\end{array}$ \\
\hline Intercept & $\begin{array}{c}-0.1140 * * \\
(-5.1903)\end{array}$ & $\begin{array}{c}-0.1176 * * \\
(-4.5899)\end{array}$ & $\begin{array}{c}0.0914 * * * \\
(6.3611)\end{array}$ & $\begin{array}{c}-0.1140 * * \\
(-4.9976)\end{array}$ & $\begin{array}{c}-0.1176 * * \\
(-4.3136)\end{array}$ & $\begin{array}{c}0.0914 * * * \\
(6.9184)\end{array}$ & $\begin{array}{c}0.0125 \\
(0.3874)\end{array}$ & $\begin{array}{c}0.0208 \\
(0.5382)\end{array}$ & $\begin{array}{c}0.1144^{* * *} \\
(3.6862)\end{array}$ \\
\hline Industry dummies & Yes & Yes & Yes & Yes & Yes & Yes & Yes & Yes & Yes \\
\hline Year dummies & No & No & No & No & No & No & Yes & Yes & Yes \\
\hline $\mathrm{N}$ & 1040 & 1040 & 1040 & 1040 & 1040 & 1040 & 1040 & 1040 & 1040 \\
\hline Adj. $R^{2}$ & 0.2873 & 0.2425 & 0.1794 & 0.2873 & 0.2425 & 0.1794 & 0.2710 & 0.2217 & 0.1585 \\
\hline
\end{tabular}

Notes: This table reports the results of the alternative statistical approaches: Fama-MacBeth estimation (Columns 1-3); Fama-MacBeth estimation with Newey-West standard errors (Columns

4-6), and firm random effect estimation (Columns 7-9). DSCORE is the total disclosure score. GSCORE is the governance disclosure score. FSCORE is the financial disclosure score.

DISTANCE is computed as the natural logarithm of one plus distance in kilometers to the Paris region. SIZE is computed as the natural logarithm of firm total assets. LEVERAGE is calculated as the ratio of total debt to common equity. ROA is firm profitability measured as earnings before extraordinary items divided by total assets. BIG4 a dummy variable equals one if firm's accountants are certified by at least one BIG4 accounting firm, and zero otherwise. ANALYST computed as the number of analysts following the firm in year t. XLIST a dummy variable that equals one if the firm's shares are traded on foreign markets, and zero otherwise. LIQUIDITY measured as the ratio of current assets over current liabilities. MB is firm growth measured as the ratio of market value of equity to book value of equity. ISSUE a dummy variable equals one if the firm issues debt or equity securities in the year $t$ or the two years following year $t$, and zero otherwise. Industry dummies following Campbell's (1996) classification are included in all regressions. Year dummies are included in columns 7-9. The superscripts asterisks *, **, and *** denote statistical significance at the $0.10,0.05$, and 0.01 levels, respectively. 